\title{
Strain accommodation in transitional rifts: extension by magma intrusion and faulting in Ethiopian rift magmatic segments
}

\author{
M. CASEY ${ }^{1}$, C. EBINGER ${ }^{2}$, D. KEIR ${ }^{2}$, R. GLOAGUEN ${ }^{2.3}$ \& F. MOHAMED ${ }^{2}$ \\ ${ }^{\prime}$ Earth Sciences, School of Earth and Environment, University of Leeds, Leeds LS2 9JT, UK \\ (email: m.casey@earth.leeds.ac.uk) \\ ${ }^{2}$ Department of Geology, Royal Holloway University of London, Egham TW20 OEX, UK \\ ${ }^{3}$ TU Bergakademie Freiberg, Institut für Geologie, B. von Cotta 2, D-09599 Freiberg, Germany
}

\begin{abstract}
Active deformation within the northern part of the Main Ethiopian Rift (MER) occurs within approximately $60 \mathrm{~km}$-long, $20 \mathrm{~km}$-wide 'magmatic segments' that lie within the $80 \mathrm{~km}$ wide rift valley. Geophysical data reveal that the crust beneath the <1.9 Ma magmatic segments has been heavily intruded; magmatic segments accommodate strain via both magma intrusion and faulting. We undertake field and remote sensing analyses of faults and eruptive centres in the magmatic segments to estimate the relative proportion of strain accommodated by faulting and magma intrusion and the kinematics of Quaternary faults. Up to half the $\leq 10 \mathrm{~km}$-Iong normal faults within the Boset-Kone and Fantale-Dofen magmatic segments have eruptive centres or extrusive lavas along their length. Comparison of the deformation field of the largest Quaternary fault and an elastic half-space dislocation model indicates a down-dip length of $10 \mathrm{~km}$, coincident with the seismogenic layer thickness and the top of the seismically imaged mafic intrusions. These relations suggest that Quaternary faults are primarily driven by magma intnusion into the mid- to upper crust, which triggers faulting and dyke intrusion into the brittle upper crust. The active volcanoes of Boset, Fantale and Dofen all have elliptical shapes with their long axes in the direction N105. consistent with extension direction derived from earthquake focal mechanisms. Calderas show natural strains ranging from around 0.30 for Boset. 0.55 for Fantale, and 0.94 for Dofen. These values give extension strain rates of the order of 0.3 microstrain per year, comparable to geodetic models. Structural analyses reveal no evidence for transcurrent faults linking right-stepping magmatic segments. Instead, the tips of magmatic segments overlap, thereby accommodating strain transfer. The intimate relationship between faulting and magmatism in the northern MER is strikingly similar to that of slow-spreading mid-ocean ridges, but without the hard linkage zones of transform faults.
\end{abstract}

Fault and magmatic structures within the transition zone between continental and oceanic rifting are masked by thick wedges of seaward-dipping lavas on the majority of passive continental margins worldwide (e.g. Korenaga et al. 2003; Holbrook $\&$ Kelemen 1993). As a result, there are few quantitative data on strain distribution immediately prior to continental breakup, nor on the along-axis variations of a clearly 3D process. Thus, we cannot discriminate between the increasingly more complex models for rupture of rheologically layered continental lithosphere (e.g. Buck 2004). The role of magmatism in the continental breakup process is also poorly understood (e.g. Buck 2004).

Oceanic rift zone studies provide important insights into the relative imporlance of faulting and magmatism. In lceland, tensile stresses from farfield plate motions accumulate over decades before being released during relatively short time periods by faulting and dyke intrusions (e.g. Bjornsson 1985; Jonsson et al. 1997). The magma injection is expressed at the surface by surface uplift due to increased pressure in the underlying magma source and, locally, by shallow seismicity (e.g. Sigmundsson et al. 1997; Feigl et al. 2000). In the Southern Iceland Seismic Zone and Aden rift, magma injection at the base of the brittle crust may induce stresses that exceed the Coulomb failure threshold, thereby triggering earthquakes (Feigl et al. 2000; Cattin et al. 2005). On the Upper East Rift Zone of the Kilauea volcano in Hawaii, seismic swarms with events of magnitude 3 and less are accompanied by dyke intrusions at shallow depth (Cervelli et al. 2002). The alongstrike propagation of dykes is further facilitated by the local increase of tensile stresses at the tips of the advancing magma-filled fissures (Rubin \& Pollard 1988; Rubin 1992). A separate group of models considers strain accommodation by faulting processes without magma intrusion. Within the incipient seafloor spreading centres of the Afar depression, Acocella et al. (2003), Manighetti et al. (1997) and Gupta \& Scholz (2000) proposed that Quaternary normal faults nucleate from 
tensile stress-induced fractures as they grow downward and along strike, with a mechanism similar to that proposed for oceanic ridges in Iceland (Gudmundsson 1992) and at the East Pacific Rise (Wright et al. 1995). Alternatively, Grant \& Kattenhorn (2004) propose that en echelon fissures in Iceland formed above upward-propagating, dipping normal faults.

New and existing data from the seismically and volcanically active Main Ethiopian Rift, East Africa, demonstrate its similarities to mid-ocean ridges, yet within a continental setting. Uniquely, we have the opportunity to capture processes in a rift transitional between continental and oceanic rifting. Field studies in the MER and Afar depression have documented that dyking and faulting, mostly localized in $<20 \mathrm{~km}$-wide magmatic segments, accommodate extension (Hayward \& Ebinger 1996; Ebinger \& Casey 2001). The relative proportion and process, however, remain debated (e.g. Acocella et al. 2003). The aims of our field and remote sensing studies are to (1) characterize structural patterns in four magmatic segments along the length of the rift; (2) estimate strain accommodation by faulting and magma intrusion in two magmatic segments; and (3) integrate these results with those of complementary geophysical studies in the rift to propose a model for the transition from continental to oceanic rifting. Our work, integrated with the EAGLE geophysical data, indicates that the alongaxis segmentation of this transitional rift is largely controlled by magmalic intrusion, rather than segmented extensional fault systems.

\section{Tectonic setting}

The Main Ethiopian Rift system developed within an Oligocene flood basalt province, and it overlies a broad region of anomalously low velocity mantle (e.g. Montelli et al. 2004; Benoit et al. 2003; Bastow et al. 2005) (Fig. 1). A synthesis of ${ }^{40} \mathrm{Ar} /{ }^{39} \mathrm{Ar}$ data shows that up to $2 \mathrm{~km}$ of flood basalts and rhyolites were erupted throughout the southernmost Red Sea region at around $31 \mathrm{Ma}$ (e.g. Hofmann et al. 1997; Pik et al. 2003), roughly coeval with the separation of Arabia from Africa (Wolfenden et al. 2005). Less widespread and probably related volcanism affected SW Ethiopia at 45-39 Ma (e.g. Ebinger et al. 2000), and volcanism continued outside the developing rifts until around $11 \mathrm{Ma}$ (Kieffer et $a l$. 2004) when volcanism was localized to the rift valleys. The volcanic units overlying uplifted Mesozoic marine sequences now form a $2500 \mathrm{~m}$-high plateau on both sides of the southern Red Sea and western Gulf of Aden (Fig. 1). Thus, the long-lived volcanism throughout the $1000 \mathrm{~km}$-radius region suggests the asthenospheric hot zone is also long-lived.
The triple junction between the Red Sea, Gulf of Aden and the Main Ethiopian Rift, the northernmost sector of the East African rift system, lies within the Afar depression west of the Danakil microplate (e.g. Manighetti et al. 1997; Tesfaye et al. 2003) (Fig. 1). Oligocene extension in both the Red Sea and Aden rifts was northeast-directed, and linked to the separation of Arabia from Africa (e.g. Courtillot et al. 1987; Bellahsen et al. 2003). WNW-directed extension within the third arm of the triple junction, the Main Ethiopian Rift (MER), commenced at around $18 \mathrm{Ma}$ in southwestern Ethiopia, and propagated northward into the Afar depression after $11 \mathrm{Ma}$ (Wolfenden et al. 2004; WoldeGabriel et al. 1990). Ihus, the MER is a much younger, and less evolved, rift than the Red Sea and Gulf of Aden rifts.

Seismic and geochemical data provide constraints on melting and melt emplacement beneath the MER. P- and S-wave tomography models indicate that the lithosphere-asthenosphere boundary lies at around $70 \mathrm{~km}$ subsurface with anomalously Iow velocity zones in the upper asthenosphere attributed to a combination of higher temperatures and the presence of partial melt (Bastow et al. 2005). Major element compositions of Quaternary mafic lavas from the MER are derived from parental melts generated at depths of $60-75 \mathrm{~km}$ (Rooney et al. 2005; Furman et al. 2006), consistent with the tomographic estimates of the lithosphereasthenosphere boundary. Analyses of SKS shear wave splitting observations indicate that partial melt accumulates in vertically oriented dykes that cross cut the lithosphere (Kendall et al. 2005; Keir et al. 2006). Thus, there is, and probably has been, a ready supply of melt to the northem MER.

Geophysical and geochemical data show magmatic modification to the crust throughout the plateau region, and its relation to fault-controlled extension. Crustal thickness is greatest (40$50 \mathrm{~km}$ ) beneath the uplifted plateau flanking the rift valley (Dugda et al. 2005: Stuart et al. 2006), with evidence for $10-15 \mathrm{~km}$ of magmatic underplate beneath the uplifted plateau where volcanism spans $>40 \mathrm{Ma}$ (Mackenzie et al. 2005) (Fig. 2). Beneath the MER, crustal thickness decreases from $\sim 38 \mathrm{~km}$ in the south to $26 \mathrm{~km}$ bencath Fantale volcano in the southern Afar depression, with a significant decrease north of Boset volcano (Dugda ef al. 2005; Maguire et al. 2006). Refraction, receiver function and gravity data suggest that (a) crustal stretching is minor south of Fantale volcano ( $9^{\circ} \mathrm{N}$; Figs $2 \& 3$ ) and (b) that the crust comprises an increasingly larger proportion of new igneous material as one moves from south to north (Mackenzie et al. 2005; Tiberi et al. 2005; Dugda et al. 2005; Cornwell et al. 2006). Ayale et al. (2006) interpreted systematic 


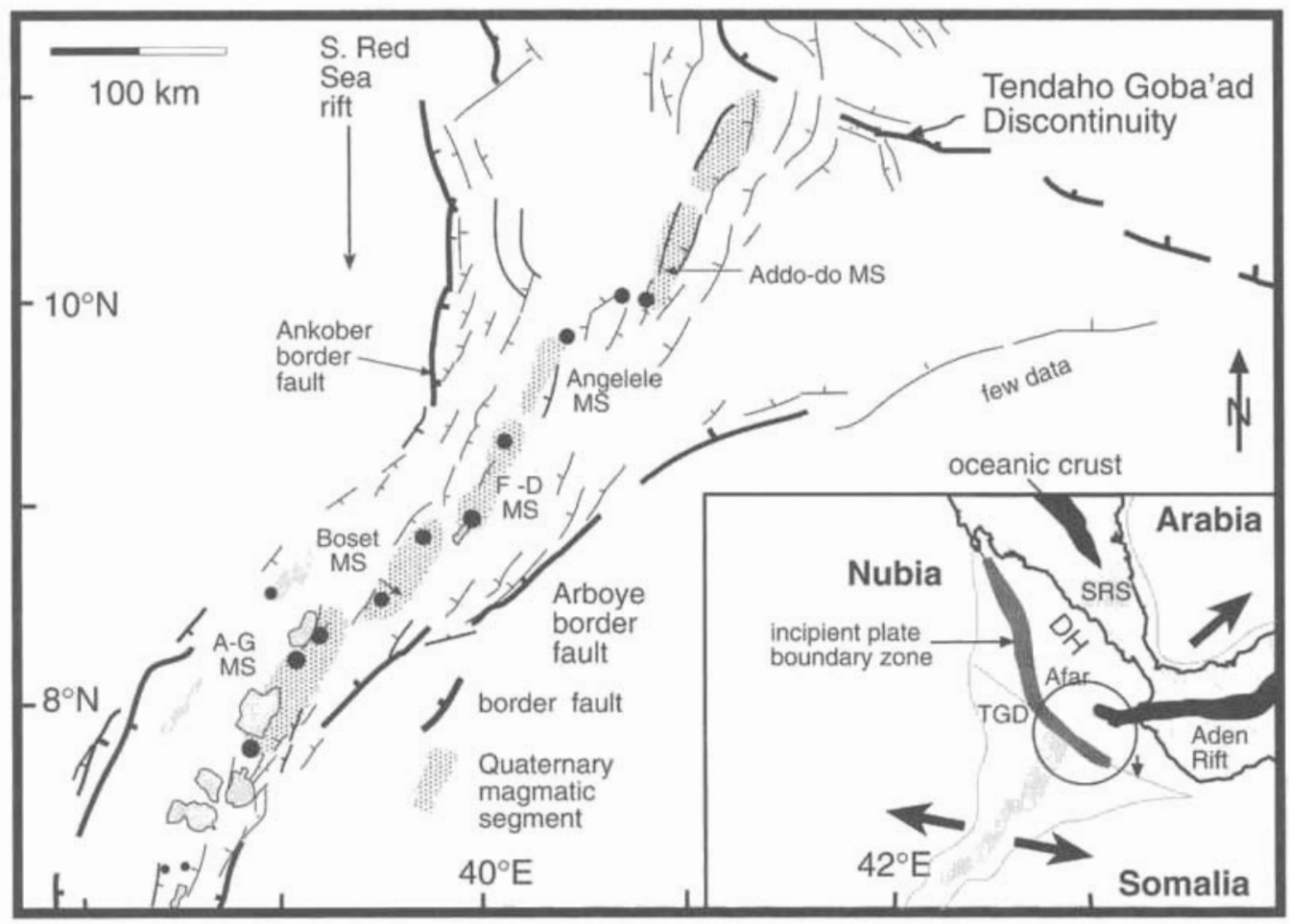

Fig. 1. Zones of Quaternary faulting and magmatism (magmatic segments) with respect to border faults of the Main Ethiopian Rift (MER) and the southern Red Sca rift. Inset shows the plate kinematic relation of the MER to the southern Red Sea and Gulf of Aden rifts, and opening directions between the Nubian, Somalian and Arabian plates. A-G: Aluto-Gedemsa, F-D: Fantale-Dofen, SRS: Southern Red Sea, DH: Danakil Horst, TGD: Tendaho Goba'ad Discontinuity. Black dots indicate locations of mahir shicld complexes After Wolfenden et al. (2004).

changes in the chemistry of felsic lavas as increasing amounts of crustal melting over the period 31 Ma to present, consistent with the spatial localization of strain.

In the northernmost Main Ethiopian Rift, a system of aligned Quaternary eruptive centres forms a right-stepping, en echelon array within the rift valley, which is bounded by mid-Miocene border faults (İbinger \& Casey 2001; Wolfenden et al. 2004). These Quaternary magmatic segments are superposed on the older Red Sea and Gulf of Aden rift structures within the Afar depression (Hayward \& Ebinger 1996; Boccalctti et al. 1999: Acocclla $e$ al al. 2003). Historic and local seismicity patterns indicate that $\mathrm{N} 45$-trending border faults are inactive and that strain is accommodated within the less than $20 \mathrm{~km}$-wide magmatic segments (Keir et al. 2006). A discrete cluster of activity coincides with the oblique intersection of the Red Sea and MER rifts (Keir et al. 2006) (Figs I \& 2).

Geodetic, fault slip and seismicity data place strong observational constraints on the current opening direction along the MER, and seafloor spreading patterns constrain motions back to about 3.2 Ma. Fernandes et al. (2004) and Calais et al. (2006) predict $6-7 \mathrm{~mm} \mathrm{a}^{-1}$ opening in a direction N95 \pm 5 based on models of instantancous GPS and fault slip data. Pizzi et al. (2006) analysed fault slip indicators in dated Quaternary lavas, and found an extension direction of N95. Keir et al. (2006) inverted focal mechanism solutions for earthquakes in the northern MER occurring over a 15month period, and they estimate an extension direction of N109 \pm 12 , which is identical to the opening direction from a single geodetic profile across the rift (Bilham et al. 1999). Chu \& Gordon (1999) find an opening direction of $\mathrm{N} 105$ with an opening velocity of $6 \mathrm{~mm} \mathrm{a}^{-1}$ with plate kinematic data averaged over the past $3.2 \mathrm{Ma}$. The similarity of these independent estimates suggests that opening directions of N135 based on fault kinematic indicators alone (e.g. Acocella \& Korme 2002) may be averaging pre-3.2 Ma (N135E) and present day (N105E) opening directions. 


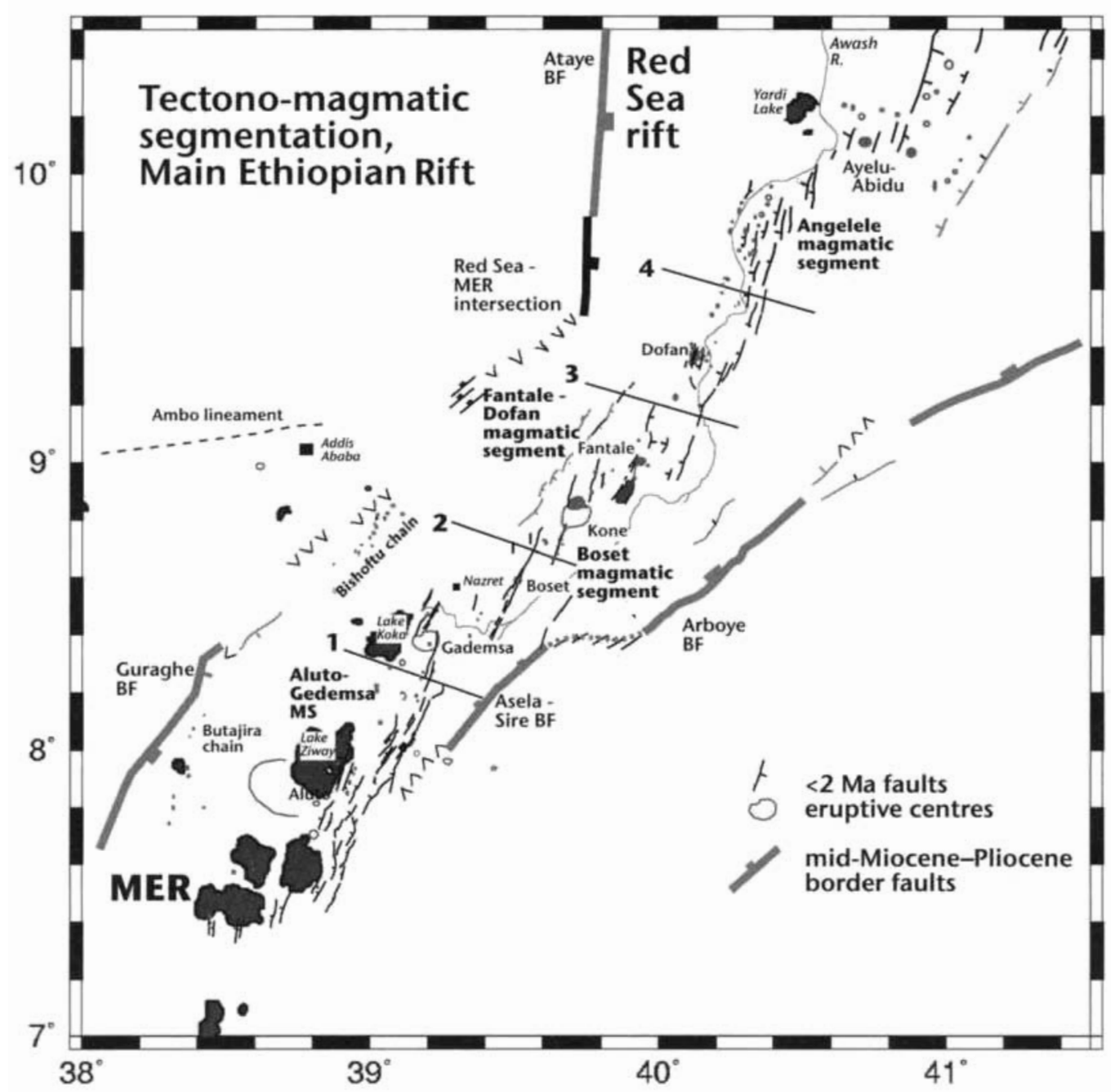

Fig. 2. Locations of Quaternary fault systems and eruptive magmatic centres with respect to the large offset $(2-5 \mathrm{~km})$ Miocene--Recent border faults of the northern MER. Note also the Butajira and Debre Zeit chains of eruptive volcanic centres to the west of the Aluto-Gedemsa and Boset-Kone magmatic segments. There are no faults with measurable throws along these aligned chains, unlike the magmatic segments. Lines 1-4 are locations of topographic profiles shown in Fig. 4.

\section{Magmatic segments}

Right-stepping en echelon faults, fissures and chains of Quaternary eruptive centres were collectively referred to as the Wonji belt, which Mohr (1962) and Meyer et al. (1975) interpreted as a riftward migration of strain from border faults. With better geochronology data and imagery, Ebinger \& Casey (2001) delineated a Quaternary along-axis segmentation of faults and eruptive centres, and described a series of magmatic segments within the loosely defined Wonji belt. This narrow, heavily faulted zone fades out south of $7.5^{\circ} \mathrm{N}$ where collapse calderas and faults occur across a much broader zone within the rift, and border faults are seismically active (Asfaw 1992; Keir et al. 2005). The N10striking faults and aligned volcanic chains within the Quaternary magmatic segments of the Wonji belt are oblique to the N45 strike of the large oftset Miocene border faults bounding the MER, which themselves are oblique to the $\mathrm{N} 20$ trend of the southern MER (e.g. Meyer et al. 1975; Pizzi et al. 2006) (Figs $2 \& 3$ ).

The Wonji belt is segmented at the surface and at depth. Tomographic images reveal an along-axis segmentation in crust and upper mantlc velocity 
patterns that follows the same right-stepping pattern as the magmatic segments of the Wonji belt. Bastow et al. (2005) image segmented, NE-trending low-velocity zones beneath the magmatic segments, which they interpret as discrete zones of enhanced melt production in the mantle. The low-velocity zones are offset slightly from the rift axis towards the NW. The magmatic segments are characterized by positive Bouguer anomalies (Tiberi et al. 2005; Cornwell et al. 2006) and underlain by anomalously high-velocity material interpreted as cooled mafic intrusions (Keranen et al. 2004). Keranen et al. (2004) tomographically image a clear rightstepping pattern of high velocities between $20 \mathrm{~km}$ and $7 \mathrm{~km}$ in the crust beneath magmatic segments.

There are also two chains of Quaternary magmatism within the MER: the Debre Zeit (Bishoftu) lineament, and the Butajira lineament (e.g. Mohr 1968; Rooney et al. 2005) (Fig. 2). Unlike the Wonji belt magmatic segments, these chains are largely aseismic and show little structural or morphological evidence of active strain (Keir et al. 2006). They are underlain by hot asthenosphere (Bastow et al. 2005), but they lack the large relative positive Bouguer anomalies of the magmatic segments (Cornwell et al. 2005). Keir et al. (2006) suggest that these are either unfavourably oriented 'failed' magmatic segments, or incipient zones of strain.

Several models have been proposed for the along-axis segmentation of the northern MER. The obliquity of Miocene border faults and Quaternary faults in the Wonji belt led Bonini et al. (1997) to propose a model of oblique extension along the border faults after a change in extension direction, which probably occurred at around 3.5 Ma to accommodate along-axis propagation in the Gull of Aden (Wolfenden et al. 2004). The Quaternary development, therefore, of the Wonji belt (our magmatic segments) has been attributed to oblique extension, with a left-lateral component of motion along the rift floor (e.g. Mohr 1968; Boccaletti et al. 1998).

Alternatively, Meyer et al. (1975) recognized the Wonji belt as a tectonic and magmatic rift stage transitional between continental and oceanic rifting, with a narrow zone of magma intrusion. Ebinger \& Casey (2001) and Keranen et al. (2004) likened the 'magmatic segments' to alongaxis segmentation seen on slow-spreading midocean ridges, based on interpretations of geophysical and geological data. The earlier kinematic models focused on mechanical deformation across the rift, and considered the magmatism a consequence of the brittle surface deformation.

We briefly describe the characteristics of this along-axis segmentation between Aluto volcano in the south and Ayclu-Abidu in the north summarizing existing constraints and illustrating with cross-rift topographic profiles extracted from $90 \mathrm{~m}$ SRTM digital elevation models (Figs 3 \& 4). This region coincides with the coverage of the EAGLE experiment, which provides critical subsurface and kinematic information to constrain surface observations (e.g. Maguire et al. 2006). Segment names are derived from the peralkaline silicic centres in each segment, rather than the geographic locales used in Ebinger \& Casey (2001), which have both Amharic and Oromiya names, leading to confusion. Segment terminations are delineated at right-steps in the zones of magmatic construction. The boundary between the partly sedimentcovered Fantale-Dofen and Angelele magmatic segments is less clear. There two right steps in the new border fault systems east of Dofen that mark the tip of the Fantale-Dofen segment. The Angelele segment to the north is marked to its east by an elliptical border fault system (Figs 2 \& 3).

\section{Aluto-Gedemsa magmatic segment}

The $20 \mathrm{~km}$-wide, $70 \mathrm{~km}$-long Aluto-Gedemsa magmatic segment corresponds to an approximately $50 \mathrm{~m}$-high dome marked by numerous collapse calderas and volcanoes (Fig. 4a). This magmatic segment shows only minor crustal thinning with respect to crustal thickness beneath the flanks (Stuart et al. 2006; Maguire et al. 2006; Tiberi et al. 2005). The $0.85-0.29 \mathrm{Ma}$ Gademsa caldera lies near the northern end of this magmatic segment (Morton et al. 1979; Boccaletti et al. 1999). Pizzi et al. (2006) provide detailed maps and interpretations of faults and eruptive centres in the Aluto-Gedemsa segment, as well as the more diffuse zone of faulting and magmatism to the south.

The morphologically youthful faults cut $1.97 \mathrm{Ma}$ basalt flows, which are overlain by a $1.6-0.6 \mathrm{Ma}$ package o[ ignimbrites, and Holocene flows (Pizzi et al. 2006). Individual faults within the magmatic segment are up to $20 \mathrm{~km}$ in length, and bound narrow horsts and grabens (e.g. Fig. 4a). Pizzi et al. (2006) estimate minimum slip rates of around $1 \mathrm{~mm}^{-1}$.

\section{Boset-Kone magmatic segment}

The c. $65 \mathrm{~km}$-long Bosct magmatic segment steps $15 \mathrm{~km}$ to the east, and lies about $500 \mathrm{~m}$ lower than, the Aluto-Gedemsa magmatic segment (Figs 3 \& 4a). The Keradi-Balchi fault system lying to the west of the magmatic segment developed between 3.2 and $2.5 \mathrm{Ma}$, but morphology and seismicity patterns indicate that it is now inaclive (Wolfenden et al. 2004; Keir et al. 2006).

The c. $1.9 \mathrm{Ma}$ Wonji series marks the base of the magmatic segment (WoldeGabriel et al. 1990; 


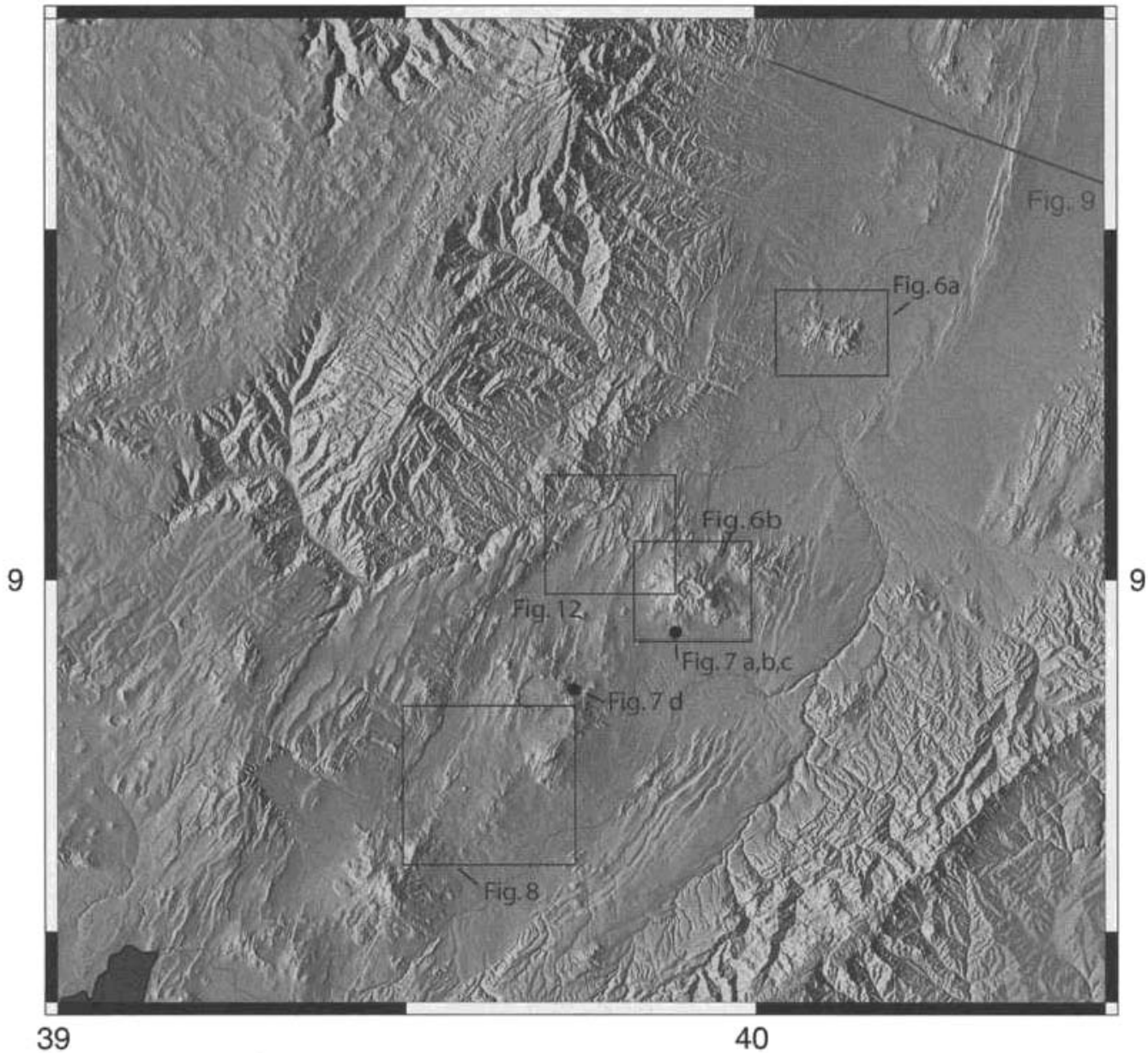

Fig. 3. $90 \mathrm{~m}$ SRTM greyscale digital elevation model showing the locations of the areas corresponding to tigures. Note the consistent decrease in elevation from south to north along the length of the rift.

Boccaletti et al. 1998; Kidane et al. 2006). Boset (Bosetti) volcano lies near the southern tip of the segment, and the elongate, multiphase Kone caldera lies near its northern end (Figs 2 \& 3). Morton et al. (1979) report an age of $0.79 \mathrm{Ma}$ for the basal trachytes of Boset. Williams et al. (2004) constrain late stage eruptions to around $14000-6800 \mathrm{BP}$. Along the Boset-Kone magmatic segment, two $30-40 \mathrm{~km}$ long fault arrays and aligned chains of cinder cones are themselves arranged in a right-stepping en echelon pattern (Figs 2, 3 \& 4a).

\section{Fantale-Dofen magmatic segment}

Faults and aligned cruptive centres in the FantaleDofen magmatic segment developed within the zone of intersection of the $c .25 \mathrm{Ma}$ Red Sea rift, and the MFR (Wolfenden et al. 2004). Unlike the Aluto-Gedemsa and Boset-Kone magmatic segments to the south, the Fantale-Dofen magmatic segment lies within a half-graben bounded along its eastern side by a series of $60-80 \mathrm{~m}$-high scarps (Fig. 3; km 38, Fig. 4b). This graben lies $550 \mathrm{~m}$ below the c. $1300 \mathrm{~m}$-high Boset-Kone magmatic segment, consistent with the $>5 \mathrm{~km}$ decrease in crustal thickness north of between Boset and Fantale volcano (Maguirc et al. 2006; Stuart et al. 2006).

This magmatic segment is marked by felsic shield volcanoes with elongate calderas at both its southern (Fantale) and northern (Dofen) ends (Figs 2, $3 \&$ \& 6). Lava flows originating from a fissure located on Fantale's southern flank erupted between 1810 and 1820 (e.g. Gibson 1967; 
(a)

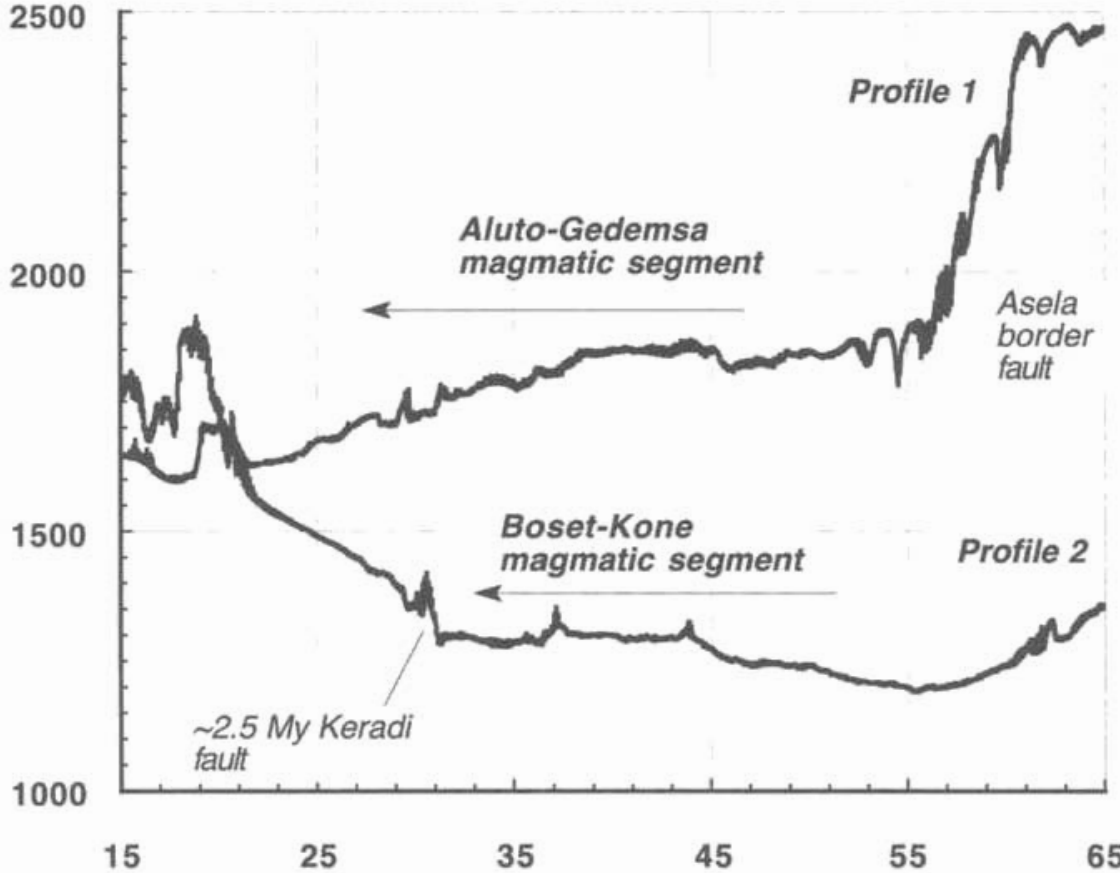

(b)

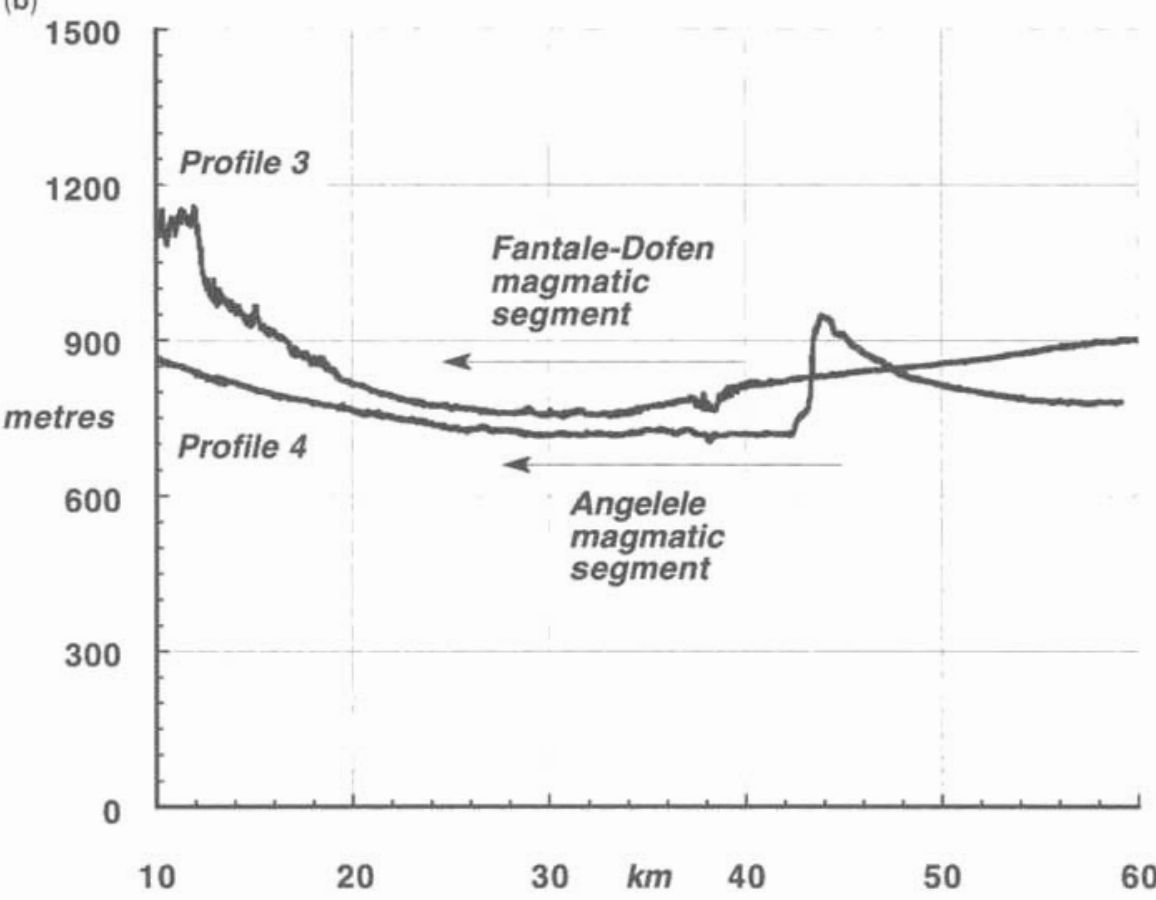

Fig. 4. Vertically exaggerated topographic profiles extracted from $90 \mathrm{~m}$ SRTM topography database to illustrate tectono-magmatic relations and their variations along the length of the rift. Profiles $1-4$ are marked on Fig. 2.

(a) Profiles 1 and 2 crossing the Aluto-Gedemsa and Boset-Kone magmatic segments, respectively. (b) Profiles 3 and 4 crossing the Fantalc-Dofen and Angelele magmatic segments, respectively. Note the change from low dome to half-graben morphology of the active tectonic zone as one moves from south to north. 


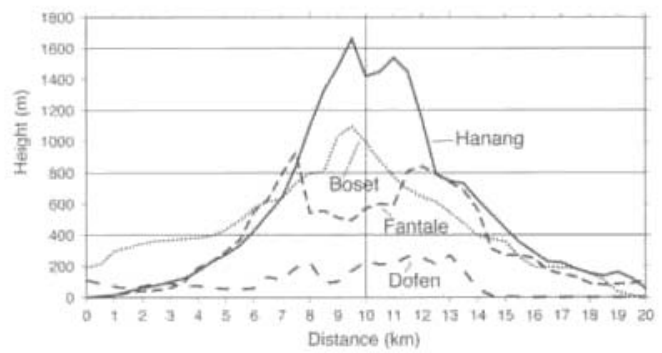

Fig. 5. Profiles through the volcanic edifices of Boset, Fantale and Dofen. The unfaulted profile of Hanang volcano (Tanzania) is shown for comparison. Geological and geophysical data show no evidence of extensional strain across Hanang (e.g. LeGall et al. 2004). The MER volcanoes are all broader and lower than Hanang; flattening increases from south to north.
Williams et al. 2004), and they are now cut by N10 E-striking faults (Figs 2, 3 \& 6a). Open fissures, and fissures with lavas, are common throughout this belt (e.g. Asfaw 1982; Williams et al. 2004). Although some $\mathrm{K}$-Ar dates for the extended apron of the Dofen volcanic complex provide dates of $1.7 \mathrm{Ma}$. historic flows and sulfur extrusions attest to ongoing activity within the central part of the rifted Dofen shield (Chernet 2005). Normal faults with $>100 \mathrm{~m}$ throw downdrop the Dofen shield complex, producing a narrow rift valley in the central caldera complex (Figs 3, 5 \& 6a). The Dofen region experienced intense seismicity during the period 2001-2003, with an approximately $M_{\mathrm{L}}=4.8$ event located $\mathrm{SE}$ of Dofen volcano (Keir et al. 2006).

(a)
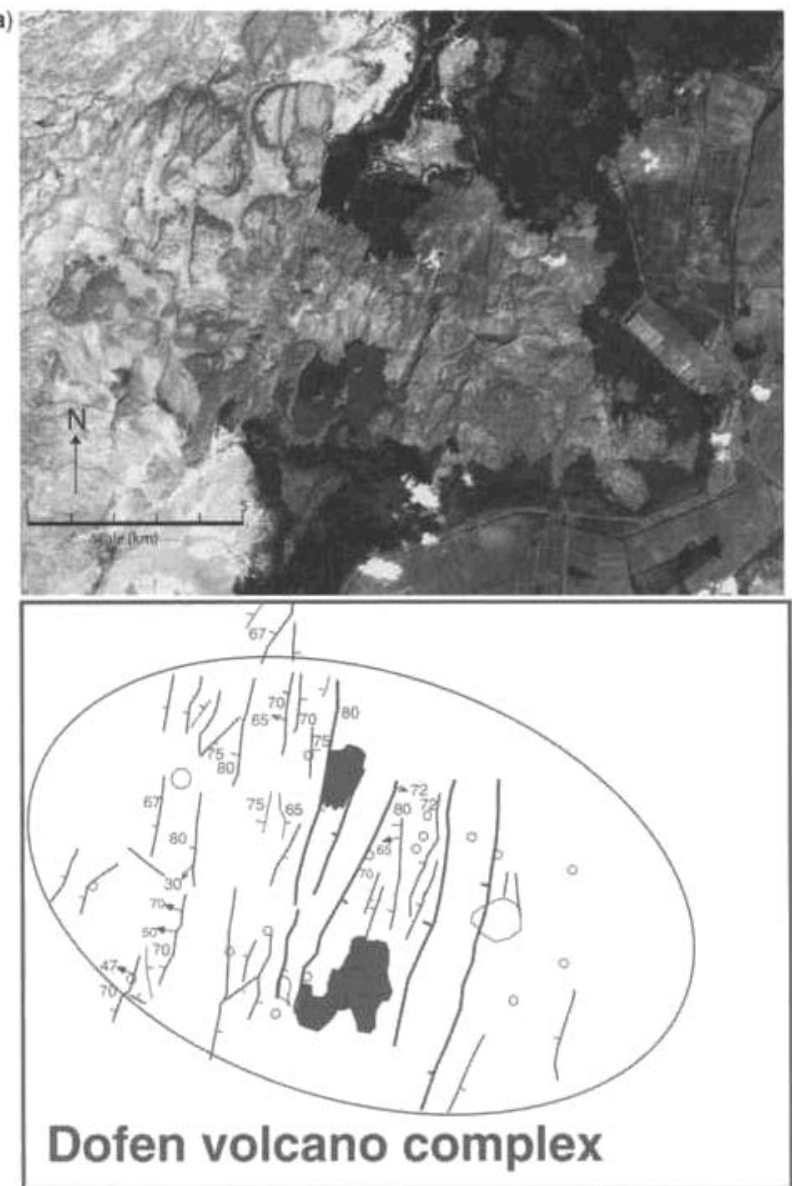

Fig. 6. (a) Band 2 of Aster $15 \mathrm{~m}$ resolution imagery showing the Dofen volcanic edifice. The elliptical region with roughly east-west long axis is taken to be the strained volcanic edifice (clipse above shows regional extension direction). Fault dips and fault slip directions from field studies in 1990 shown in line drawing below image. Open circles indicate eruptive centres. 


\section{Angelele magmatic segment}

The $60 \mathrm{~km}$-long Angelele magmatic segment has the form of a half-graben bounded on its eastern side by a $230 \mathrm{~m}$-high fault system, the largest active fault in the area (Figs $2,3 \& 4 \mathrm{~b}$ ). This 'new' border fault has an en echelon soft linkage zone with the fault system bounding the eastern side of the Fantale-Dofen magmatic segment; the individual fault segments form a right-stepping system between 9.5 and $10^{\circ} \mathrm{N}$ (Figs $2 \& 3$ ). It is also a shallow depression like the Fantale-Dofen segment to the south (Figs $3 \& 4$ b).

Geological and geophysical information is sparse in this remote region; only ASTER imagery and DEM data were used. Faults and aligned eruptive centres do not show the right-stepping pattern of magmatic segments to the south, perhaps owing to superposition of the MER on Oligocene Red Sea rift structures (e.g. Tesfaye et al. 2003). Chernet et al. (1998) provide a lone $\mathrm{K}-\mathrm{Ar}$ date of $0.83 \pm 0.02 \mathrm{Ma}$ for a basalt flow midway down the magmatic segment. Faults bounding the segment show greater throws than to the south. Keir et al. (2006) locate a number of seismic events in this magmatic segment, which lies at the limit of the EAGLE array.

\section{Structural observations}

Field sites within the Boset-Kone and FantaleDofen magmatic segments were chosen to field check satellite imagery and to examine the relation, in time and space, between faulting and magmatism. In this regional study of the Boset-Kone and Fantale-Dofen magmatic segments, we measured the lengths and orientations of faults that cut $<1.9 \mathrm{Ma}$ lava flows, as well as the position of scoria cones, fissural or vent flows, and dykes. We measure fault lengths and orientations using field-calibrated high-resolution imagery, 1:50000) topography sheets, and 90 m-resolution SRTM. Landsat Thematic Mapper imagery (15$30 \mathrm{~m}$ resolution) and ASTER imagery $(15 \mathrm{~m}$ resolution) provide a regional context, and field traverses were made on all but the Angelele magmatic segment. We confined our study to faults of length greater than $200 \mathrm{~m}$ that were clearly distinguishable from felsic and basaltic flow fronts (e.g. Figs 6 \& 8). Fault displacements can only be estimated from topographic relief, as vertical resolution of seismic data is about $500 \mathrm{~m}$ in the shallow subsurface. We therefore do not examine lengthdisplacement relations in this regional study. Faults immediately outside the Quaternary magmatic (b)

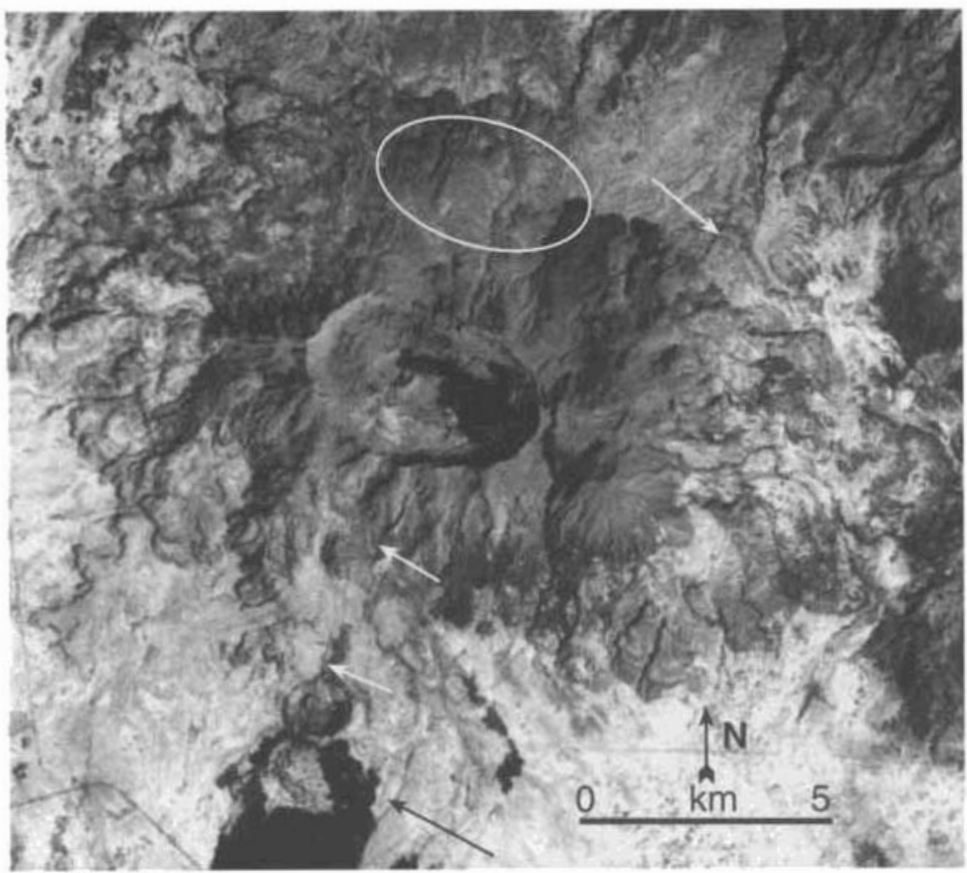

Fig. 6. Continued. (b) Landsat- 7 Thematic Mapper ( $30 \mathrm{~m}$ resolution) image of Fantale volcanic edifice. Arrows point to active NIOE fault scarps. 
segments show little or no seismicity and are more deeply incised. These faults are also excluded from our database.

An example of the observations used to interpret Quaternary faults is shown later in Fig. 11. The fault scarp in the foreground shows the relay zone between two segments. The segments seen here are typical of their regularity in the Quaternary faults. The faults are often marked at the surface by a vertical fissure that may have very little movement (Fig. 7a). The fissure sometimes separates a rotated block of rock and the upthrow side of the fault (Fig. 7c). Figure $7 \mathrm{~b}$ is a view onto the surface of the rotated block, which forms a smooth monoclinal ramp from upthrown to downthrown side. Figure $7 \mathrm{~d}$ is a view from a relay zone towards one of the segments.

Measurements of fault, dyke, and fissure geometries were made throughout the Boset-Kone and Fantale-Dofen magmatic segments. Faults in the basalts rapidly degrade, splitting along individual columnar basalts, leading to near-vertical scarps that rarely preserve the fault slip plane. Fault kinematic indicators were only measured in the Dofen caldera complex, and contribute to our evaluation of Quaternary extension direction (Fig. 6).

There are no active large offset faults along the length of the magmatic segments, nor across the Boset-Kone magmatic segments; we can infer that there are no buried faults, as only the $2-4 \mathrm{~km}$ throws on the border faults are imaged in EAGLE seismic data (Mackenzie et al. 2005; Maguire et al. 2006). The cumulative frequency plots of all identified faults within the Boset-Kone magmatic segment $(N=123)$ and the Fantale-Dofen magmatic segment $(N=164)$ are shown in Fig. 9 . The limited length range of observations makes it speculative to interpret the completeness of the database. Clearly, many faults may be covered by sediments and/or lavas, and faults with small surface displacements will be difficult to identify in DEM and imagery.

The orientations of individual segments forming linked faults is shown in Fig. 10. We also estimate strain direction and magnitude as given by the elliptical shape of Boset, Fantale and Dofen volcanoes (e.g. Fig. 6b).

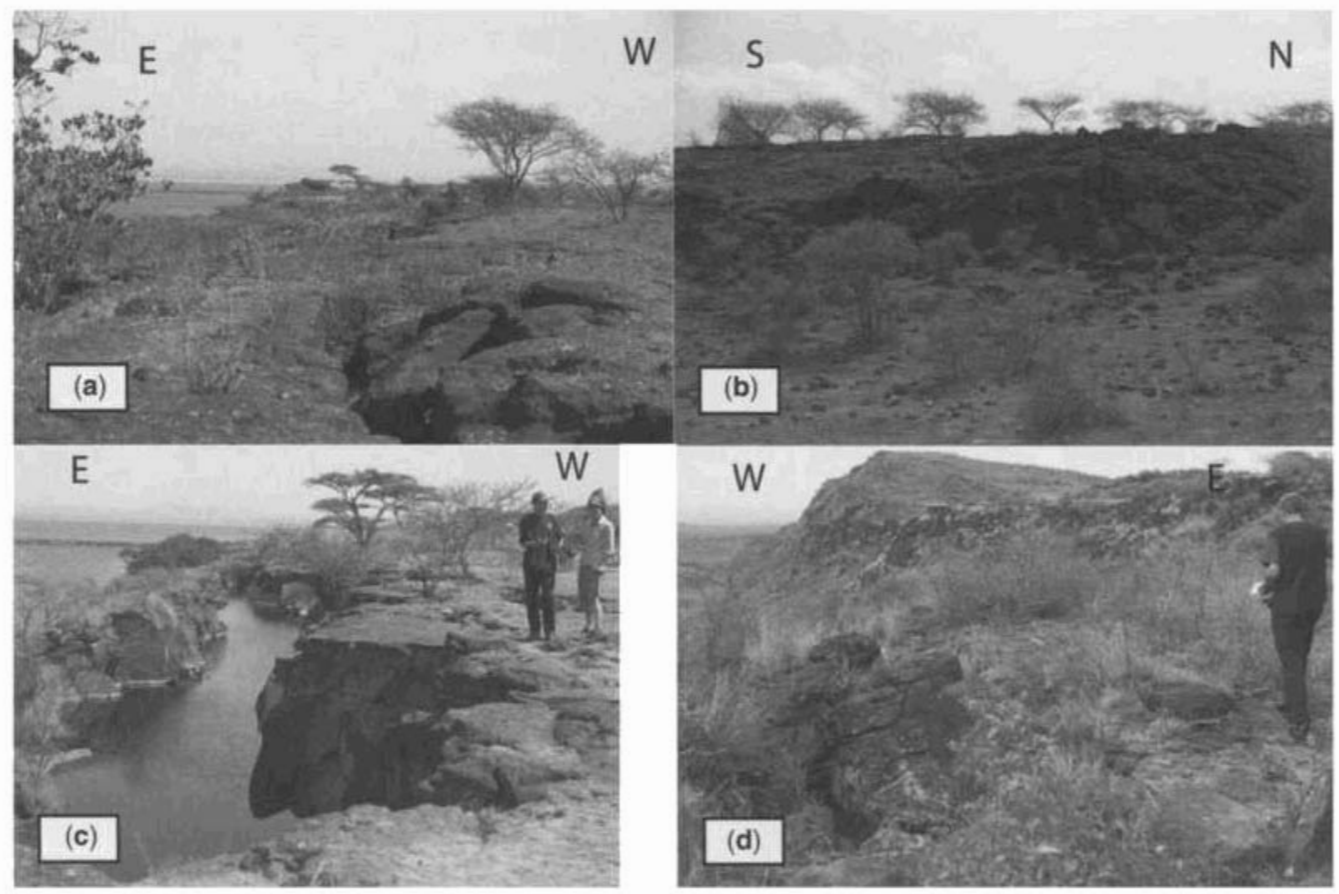

Fig. 7. laults and fissures from the overlap zone between the Boset-Kone and Fantale-Dofen magmatic segments. (a) Fissure with very little shear movement beside Lake Beseka; downthrow is to the left. (b) View onto the rotated block of a normal fault, Lake Beseka. (c) Wide fissure and rotated block (to left) L.ake Beseka. (d) Fault, relay zone and fissure, near the Kone caldera complex. The left side of the hill on the skyline gives the orientation of the fault at depth. 

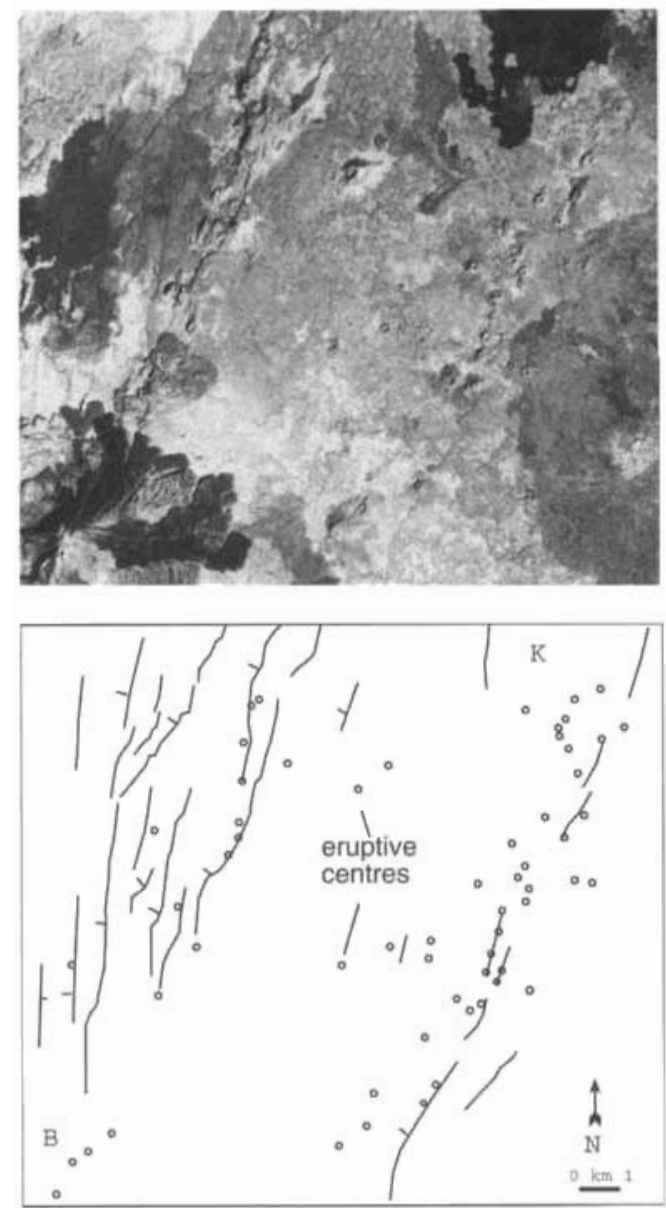

Fig. 8. Landsat TM imagery showing the close spatial coincidence of faults and eruptive centres (fissures, cinder cones, shields) on the central Boset-Kone magmatic segment. Location shown in Fig. 3. Note the parallel faults and aligned scoria cones, as well as fissural flows from some faults. Boset (B) and Kone (K). Most of the relief in this zone is magmatic construction.

The positive relief of the Aluto-Gedemsa and Boset-Kone magmatic segments deflect rivers away, whereas the shallow depressions of the Fantale-Dofen and Angelele magmatic segments capture the Awash River and its tributaries. Faults of the northern two segments, therefore, expose Pliocene-Recent ephemeral lake deposits (e.g. WoldeGabriel et al. 1990; Asfaw et al. 1992), striae and other slip indicators along faults in fluvio-lacustrine and volcaniclastic sequences. These field observations and the fault and eruptive centre analyses of imagery from the Boset-Kone and Fantale-Dofen magmatic segments reveal

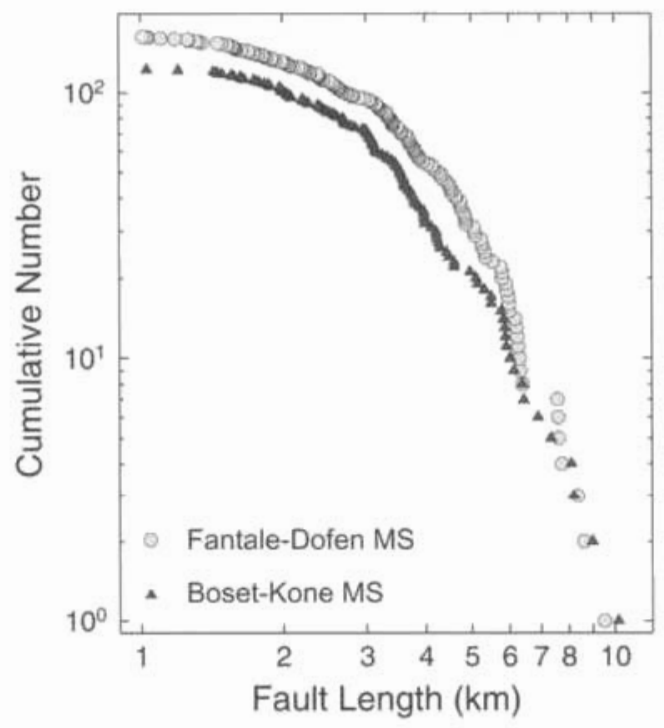

Fig. 9. Cumulative frequency plots of faults from the Boset-Kone magmatic segment and Fantale-Dofen magmatic segment.

several consistent patterns (online supplementary imagery and Table 1).

(1) Faulting and magmatism occur in c. 20$40 \mathrm{~km}$-long right-stepping arrays that lie on either side of the magmatic segment (e.g. Figs $2 \& 8$ ). Within the Boset-Kone magmatic segment, these arrays emanate from the Boset and Kone shield complexes, and faults curve slightly into these volcanoes. Faults are more numerous around the multiple collapse calderas of Kone and Dofen, suggesting some formed to accommodate magma withdrawal, rather than tectonic strain (e.g. Asfaw et al. 2006). Owing to the right-stepping nature of the chains in the Boset-Kone segment, there is no clear 'spreading axis'. The Fantale-Dofen segment, however, shows a low relief, around $10 \mathrm{~km}$-wide central graben striking north-south, with most faults and eruptive centres along the eastern side of this depression. The felsic shield volcanoes lic near the tips of the magmatic segments. suggesting the rise of magma is inhibited at segment tips, and crustal reservoirs form (e.g. Keranen et al. 2004).

(2) $51 \%$ of the faults in the Boset-Kone magmatic segment have aligned cones and/or fissures along their lengths. For example, small basaltic cones and fissural eruptions mark a $10 \mathrm{~km}$-long, $<100 \mathrm{~m}$-high, N10 E-striking fault array south of Kone caldera (Fig. 8). Fewer faults and eruptive centres are exposed in the depression of the Fantale-Dofen magmatic segment where $41 \%$ of 
a) Fantale-Dofen Magmatic Segment
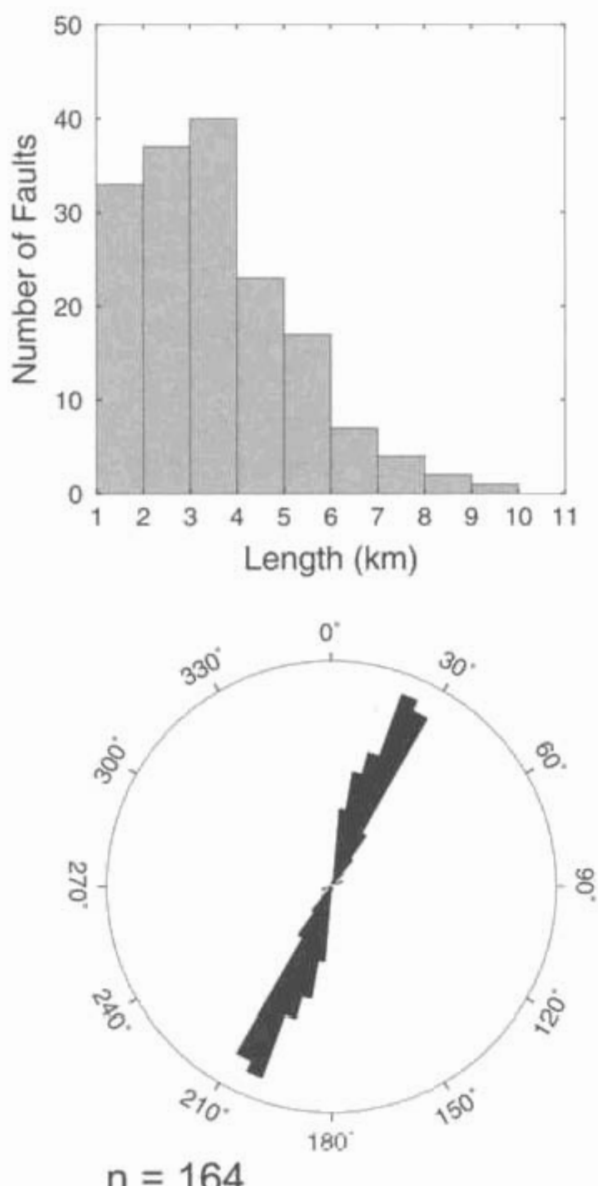

\section{b) Boset-Kone Magmatic Segment}
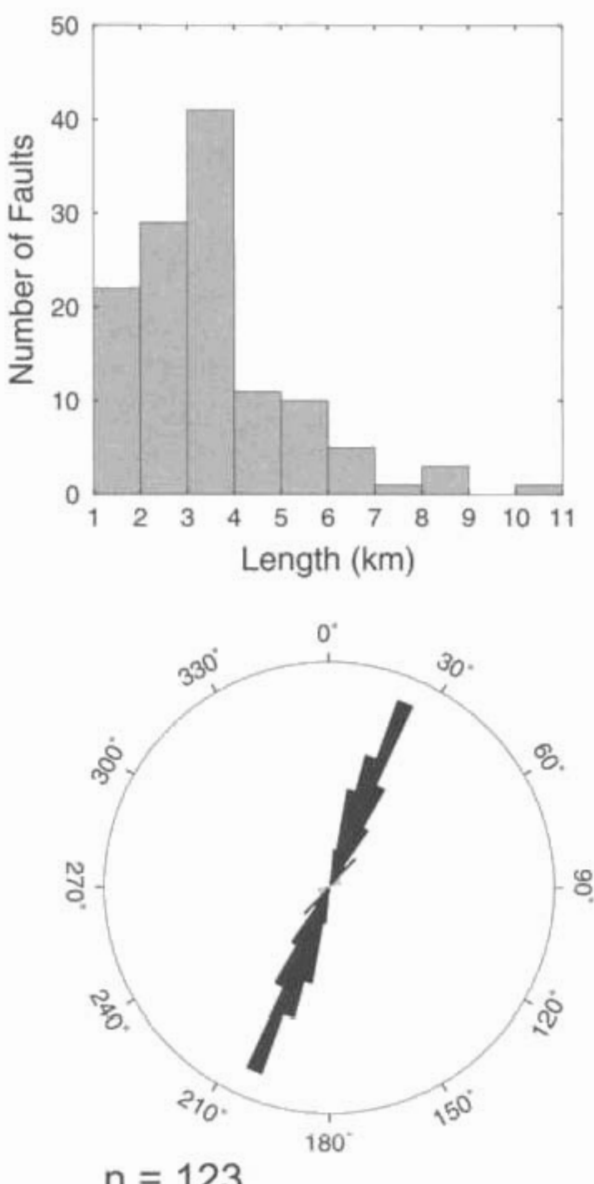

Fig. 10. Histograms of fault lengths and rose diagrams of fault azimuth for the fault populations shown in Fig 9 . (a) Fantale-Dofen magmatic segment and (b) Boset-Kone magmatic segment.

the faults have eruptive centres along their lengths, but where much of the magmatic segment is buried by recent sediments.

(3) Where the interaction between faults and cones could be clearly defined either in the field or on imagery. we found that basalts were located preferentially at the tips of the faults and open cracks (Figs 8 \& 11 ).

(4) Maximum fault length is less than $11 \mathrm{~km}$ within both the Boset-Kone magmatic segments (Figs $9 \& 10$ ). Most faults are $\leq 6 \mathrm{~km}$-long, with more faults identified in the Fantale-Dofen segment than in the Boset-Kone magmatic segment (Fig. 10). The largest fault in the Fantale-Dofen magmatic segment has a displacement of $230 \mathrm{~m}$, but faults within the Boset-Kone magmatic segment have $<80 \mathrm{~m}$ relief. More faults are detected in the Fantale-Dofen $(N=164)$ than the BosetKone $(N=123)$ magmatic segment.

(5) The majority of faults and fissures strike N10-N30 E (Fig. 10). A small subset of short faults striking $\mathrm{N} 45-70$ E link arrays within the magmatic segments (e.g. Figs 6b, 8 \& 12). Similar patterns are found in the Aluto-Gedemsa magmatic segment (Pizzi et al. 2006).

(6) Faults outside the magmatic segments show both $\mathrm{N}^{\circ} \mathrm{E}$ and $\mathrm{N} 45^{\circ} \mathrm{E}$ trends. Figure 12 shows an area of faulting between the western 
Table 1. Axial ratio, natural strain and trend of long axis estimates for some Ethiopian volcanoes

\begin{tabular}{lclcccc}
\hline Volcanic centre & Data source & Method & Height, m & Axial ratio & Natural strain & $\begin{array}{c}\text { Trend of } \\
\text { long axis () }\end{array}$ \\
\hline Dofen edifice & Landsat & Measurement & 800 & 2.56 & 0.948 & 113 \\
Dofen edifice & SRTM & Moments & 800 & 1.34 & 0.293 & 110 \\
Fantale crater & Landsat & Measurement & 1900 & 1.67 & 0.512 & 114 \\
Fantale crater & Landsat & Measurement & 1100 & 1.77 & 0.571 & 111 \\
Fantale crater & Map & Measurement & 1900 & 1.61 & 0.476 & 109 \\
Fantale edifice & SRTM & Moments & 1200 & 1.36 & 0.308 & 107 \\
Fantale edifice & SRTM & Moments & 1450 & 1.55 & 0.438 & 106 \\
Fantale edifice & SRTM & Moments & 1580 & 1.95 & 0.668 & 107 \\
Boset edifice & SRTM & Moments & 1950 & 1.31 & 0.270 & 127 \\
Boset edifice & Map & Measurement & 2100 & 1.48 & 0.392 & \\
\hline
\end{tabular}

edge of the Fantale-Dofen magmatic segment and the rift border faults, immediately north of the tip of the Boset-Kone magmatic segment. In the area labelled 'inactive faults', there are two directions of faults with rhomb-shaped regions between. The rhomb-shaped regions are often pull-apart basins into which river courses have been diverted and which contain ephemeral floodplains. The region labelled 'active faults' lies within the Fantale-Dofen magmatic segment. These faults cut $2.5 \mathrm{Ma}$ and older sequences but predate the magmatic segment formation (Wolfenden et al. 2004).

(7) There are no fault systems linking the rightstepping magmatic segments between the AlutoGedemsa and Boset-Kone magmatic segments. and between the Boset-Kone and Fantale-Dofen magmatic segments. Some short, N45-70" Estriking fault segments are noted along the length of the magmatic segments; these short faults allow linkage of en echelon faults, and may utilize Miocene-Pliocene faults (e.g. Figs 6a, 8 \& 12). Normal faults occur across the breadth of the overlapping magmatic segment tips, rather than in narrow arrays seen in the central magmatic segments.

(8) Eruptive centres are elongate in a direction parallel to the extension direction. Figure $5 \mathrm{com}$ pares the morphology of Boset, Fantale and Dofen edifices, which show a progressive flattening from south to north along the length of the rift.

The small offsets on the younger faults and the irregularity of the surface caused by lava flows and other magmatic constructs means that faults with small offsets cannot be interpreted in terms of fault deformation alone. An exception is the $30 \mathrm{~km}$-long, $250 \mathrm{~m}$-high lault escarpment bounding the east side of the Angelele magmatic segment. (Figs 4 \& 13). The easterly dipping side of the ridgc produced by the escarpment shows a section with a discernible curvature running for $10 \mathrm{~km}$ east from the ridge.

\section{Explanation of structures}

\section{Down-dip fault length from footwall uplift}

The displacement difference boundary element method of Crouch \& Starfield (1983) is a simple and convenient means of calculating the displacement ficlds around faults, which are idealised as normal fault dislocations in an elastic half-space. This idealization is seale independent. The only points of comparison between model and observations are the dimension of the fault and the distance to which the deformation field is perturbed by the presence of the fault; simulation of the footwall and hanging wall shapes would require additional assumptions beyond the scope of this study. The magnitude of the displacement on the fault has no influence on the extent of the perturbation, except that for small displacements in nature the roughness of the ground surface will mask the perturbation. A model was set up with a line of boundary elements 100 units long representing the Earth's surface: a boundary condition of zero shear and normal stress was applied. A fault dipping at 60 was defined by a 10-unitlong line of elements dipping from the mid-point of the line of elements representing the surface. A condition of zero relative normal displacement was used to hold the fault surfaces in contact. The rclative shear displacement on the fault was given a linear increase from zero at the lower end to an arbitrary value of 0.01 units at the surface.

The vertical displacement of the surface on the footwall scaled horizontally and vertically to the topographic profile is given in Fig. 13. The horizontal scaling was applied to the down-dip length of the fault. From this it may be estimated that the downdip length of the largest fault in the study area is around $10 \mathrm{~km}$ (cf. Fig. 9), consistent with the $7-10 \mathrm{~km}$ seismogenic layer thickness estimated 


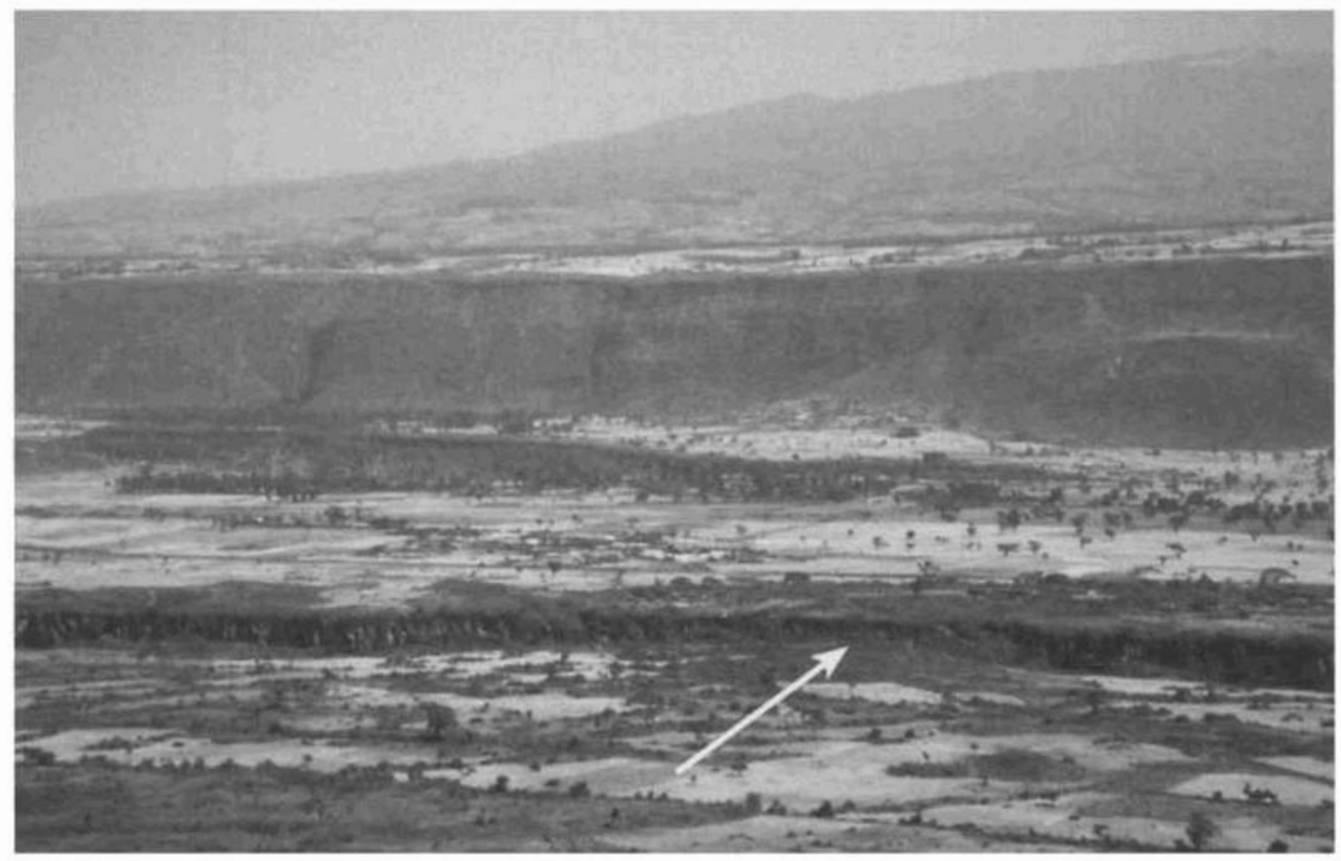

Fig. 11. Quaternary faults in the Asela region. The view direction is towards the SE, with a series of step faults leading up to the border fault in the background. The faults in the foreground show the regular segmentation of the seismically active faults. Extrusive lavas occur at segment linkage zone. Photo: Derek Keir.

by Keir et al. (2006). The topographic profile used is the one that has the longest horizontal range of footwall uplift and so the down-dip length of the fault can be taken as a maximum estimate for the faults in the region.

\section{Cinder cones and extrusions}

The concentration of cinder cones close to the magmatic segment axes had been ascribed to their being fed along axis from relatively small magma chambers under the Quaternary volcanoes (Ebinger \& Casey 2001). Geochemical and geophysical data from the EAGLE project indicate that some dykes and fissural flows are directly fed from upper mantle sources rather than from crustal reservoirs (Kendall et al. 2005; Rooney et al. 2005; Furman et al. 2006). We further propose that the regular tracks of cinder cones are the surface expression of dyke segments resulting from the variation of stress axis orientation towards the surface (Delaney \& Pollard 1981).

\section{Volcanoes as strain indicators}

The volcanic centres have elliptical forms with the long axis perpendicular to the younger normal faults, suggesting that they are the locus of strain, and record both the magnitude and the duration of strain (Fig. 6a. b). The axial ratios of three volcanoes, Dofen, Fantale and Boset, were estimated in two ways: measuring the long and short axes plus the orientation of the long axis from digital images, and by the method of De Chabalier \& Avouac (1994) (Table 1). The latter method uses the second moments of the topography, with the assumption that the extension is perpendicular to the normal faults. Deviations of the actual long axis from this direction is taken to be the result of shear strains. In this study, these deviations were so small as to be negligible. The shortening direction is taken to be vertical and this is supported by the flattened nature of these volcanic edifices, especially visible for Dofen (Figs 3 \& 5). The ratio given is thus the extension strain component. The ratio is also given as its natural logarithm, or natural strain, a strain measure that incrcases linearly with time under constant strain rate.

The data in Table 1 are quite variable according to method of obtaining the data and location of the measurements on each volcano. However, they show two trends: an increase in ratio from south to north, i.e. from Boset to Dofen; and an 


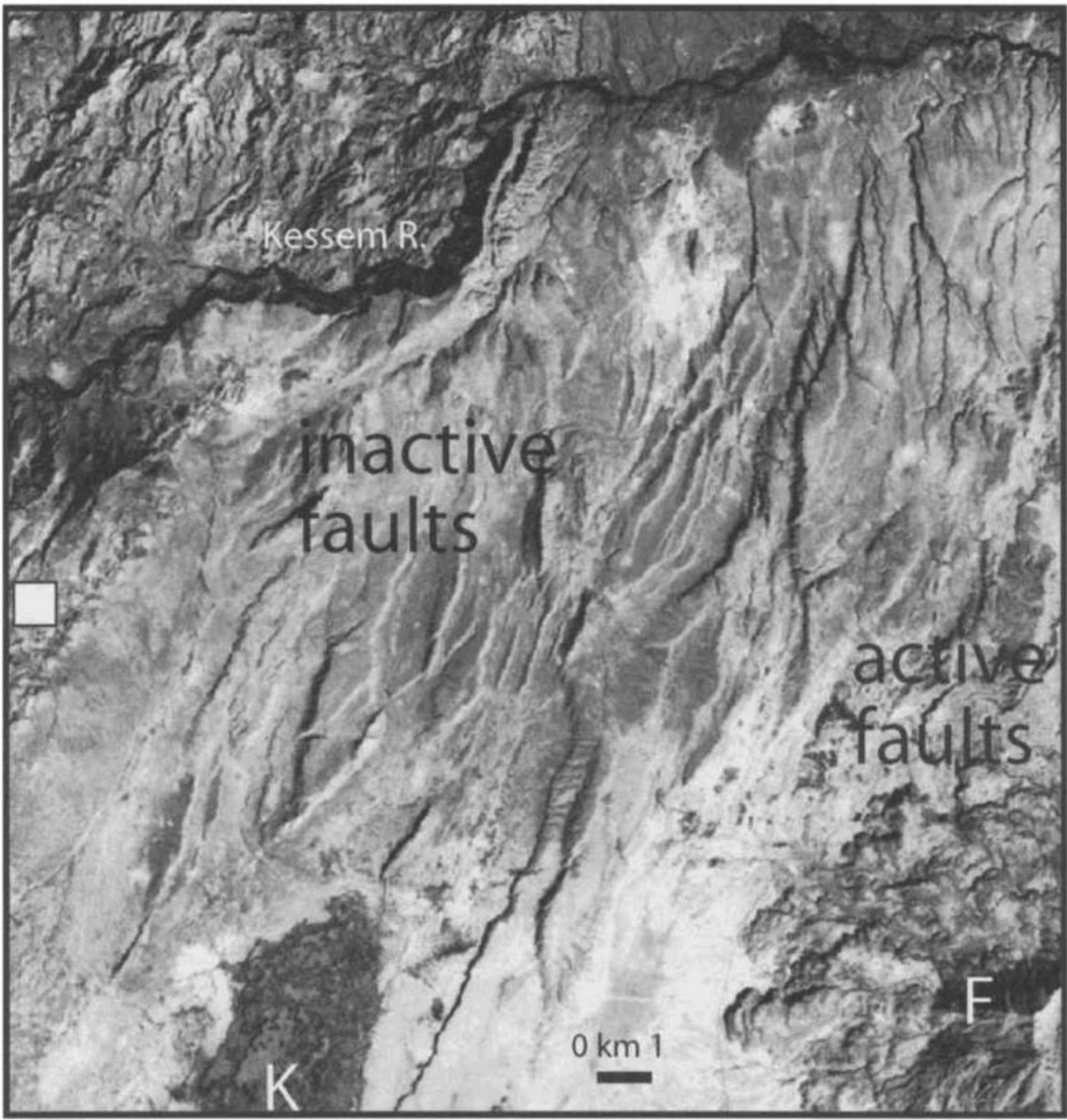

Fig. 12. Landsat TM imagery showing fault patterns outside the Quaternary Fantale-Dofen magmatic segment showing both N10E and N35E-striking, aseismic fault sets. The two fault sets intersect to form rhombohedral blocks. The active faults to the east cut the apron of Fantale volcano. The square on the left edge of the figure marks the position of a felsic ignimbrite marker bed dated at $2.5 \mathrm{Ma}$, which was used to estimate timing of fault movements (Wolfenden et al. 2004).

increase in ratio from measurements taken low to high on the volcanic editices. The long axis orientation is generally consistent at around $110 \pm 3$ except for the measurement taken from a high contour of Boset.

Figure 5 shows a comparison of the profiles of the Ethiopian rift volcanoes with an elliptical shape (e.g. Fig. 6) and Hanang volcano from Tanzania with no detectable stretching. The Ethiopian volcanoes, especially Dofen, have lower profiles than Hanang. This observation supports the hypothesis that the elliptical shape of the MER volcanoes is the result of horizontal extension and vertical shortening, in a narrow zone of magma injection (magmatic segments).

For a simple extension deformation, the strain rate can be obtained from the finite strain ratio by the following:

$$
d=\frac{\ln \left(/ / I_{0}\right)}{\Delta t}
$$


(a)

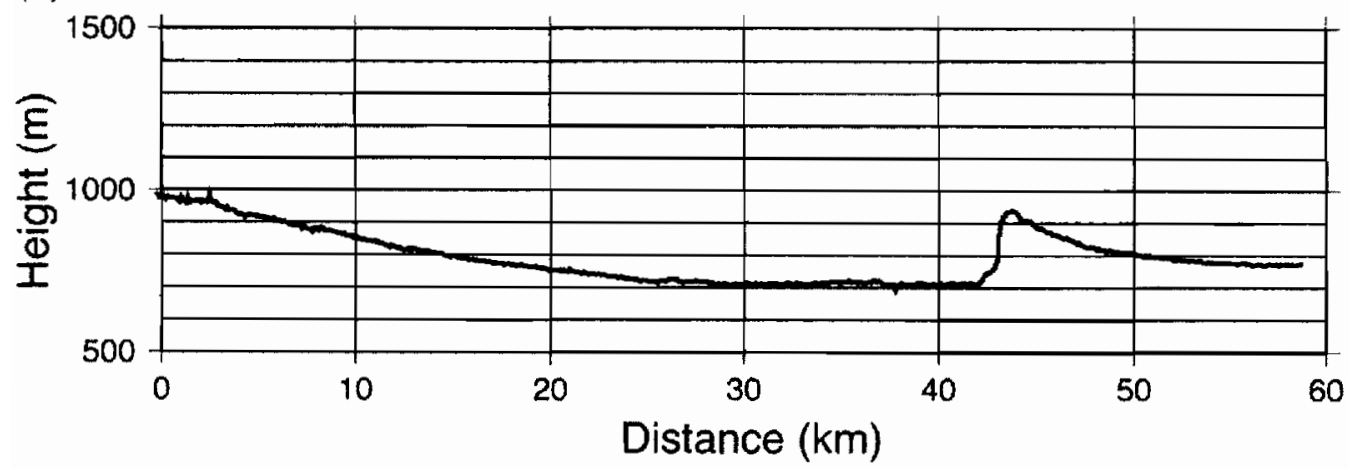

(b)

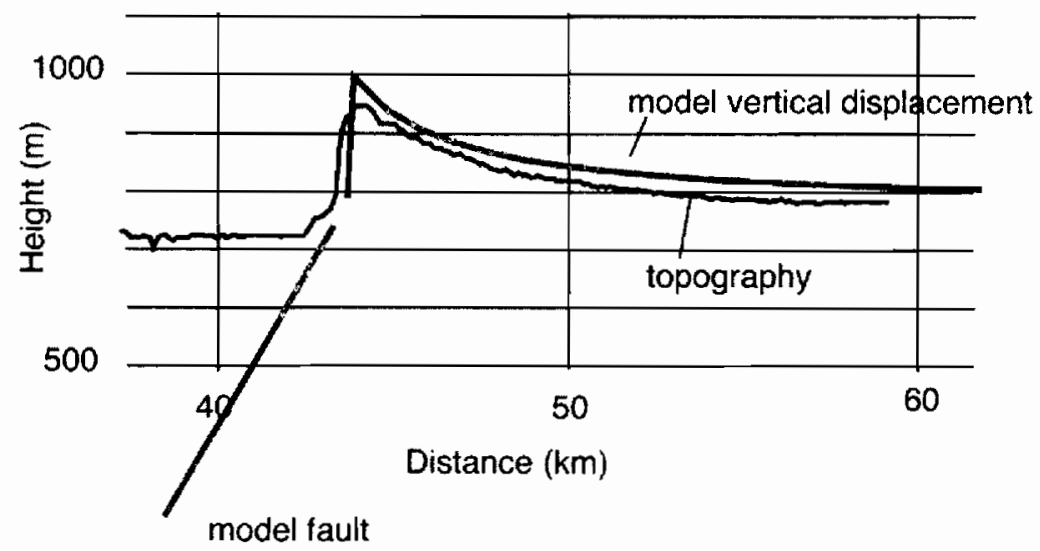

Fig. 13. (a) Detailed portion of the topographic profile through the Angelele magmatic segment (Profile 4 ,

Figs 3 \& 4b). (b) Vertical displacement of a model fault dipping at $60^{\circ}$ scaled to tit the topographic protile shown in (a). The model displacement profile has been moved upwards 10 allow comparison. The model fault, scaled by the same amount as its displacement profile is also shown in the figure.

where $d$ is the strain rate, $l$ is the deformed state length of a line of $l_{0}$ in the undeformed state and $\Delta t$ is the time over which the deformation builds up. At the spatially averaged strain rate of $0.1 \mu$ strain per ycar estimated by Bilham et al. (1999), the strains would take from 2-9 Ma to build up, a little longer than the $1.8 \mathrm{Ma}$ age of the magmatic segments. The main sources of error in comparing the strain rate estimated from the time to reach the strains observed and that from presentday geodetic measurements come from the variabijity of the latter in space and time. The relatively short times of geodetic studies raise the possibility that the measurements vary considerably from the average. The degree to which the strain is localized also has an important influence on the result. If strain is more localized than was assumed by Bilham et al. (1999), then our estimates concur within error.

\section{Discussion}

Seismicity data over the period $2001-2003$, historic seismicity and geomorphology all indicate that the Miocene border faults are inactive and strain is localized to the $c: 20 \mathrm{~km}$-wide magmatic segments. Although the planform of the MI:R between $7.5^{\circ} \mathrm{N}$ and $9^{\prime} \mathrm{N}$ is typical of analogue models of 'Iranstensional rifting', the localization of strain to the Wonji belt magmatic segments means that border faults and en echelon magmatic segments developed diachronously; differences in orientation represent the lithospheric response to changes in plate forces. Two additional lines of evidence argue against transtensional deformation for the deformation localized in the magmatic segments. Palaeomagnetic data presented by Kidane et al. (2006) show negligible rotations about vertical axes either within or between magmatic segments, as would 
be expected if the region were in fact transtensional. Focal mechanism solutions of Keir et al. (2006) show primarily dip-slip movement on N20Estriking fault planes. The minor left-lateral slip mechanisms are consistent with slip on pre-existing $\mathrm{N} 45^{\circ}$ E-striking planes within a N110E extension regime (Ayele et al. 2000; Keir et al. 2006).

The zone of rhombohedra resulting from the intersection of the two fault orientations observed between the rift border faults and the FantaleDofen magmatic segment is interpreted as a phase of transtensional deformation between $3.5 \mathrm{Ma}$ and $2.0 \mathrm{Ma}$, as noted by deformation of an ignimbrite marker bed (Fig. 12). Bonini et al. (1997) also come to this conclusion based on their model results, but these authors concluded that the transtension persists to the present day. In our interpretation, the duration of this phase of rifting is too short to accumulate measurable block rotations observable by palaeomagnetic investigations. Both models and indirect evidence from seismicity data indicate that the small offset normal faults, monoclines and open fissures form from upward propagation of both faults and faulted dykes. Magma intrusions to mid-crustal levels accommodate strain in the lower crust, and dykes and faults form in the brittle crust above intrusions (e.g. Fig. 9. Keir et al. 2006). Thus, patterns in the upper crust are similar to the model of Grant \& Kattenhorn (2004), but with magma intrusion the trigger at depth. Bull et al. (2006) show that monoclines develop beyond the lateral tips of faults in Iceland showing the same morphology as those we observed in the MER (e.g. Fig. 7b); these relations have been noted by Rowland (pers. comm., 2005). This comparison with faults in Iceland also demonstrates the similarity of process, albeit at slower rates of strain and magma production. In studying the faults on a length scale of more than around 10 metres, the presence of a vertical fissure and monocline at the surface is unimportant. Throw should be measured from the undisturbed rock on the footwall down to the undisturbed rock on the hangingwall. The orientation of the fissure (sub-vertical) should not be taken as the dip of the fault, the plane of which is some tens of metres in the subsurface.

Buck (2004) demonstrated that extension of the lithosphere can take place at a lower tectonic stress when magma is present to form dykes. If the intrusion occurs at intermediate depths (5$10 \mathrm{~km})$, the released load will be transferred upwards, driving extensional normal faults propagating towards the surface.

The deformation processes proposed here are very similar to those in the newly formed seafloor Asal-Ghoubbet rift. Cattin et al. (2005) used a visco-elastic lithospheric deformation model to simulate the observed geodetic and seismicity patterns in the Asal-Ghoubbet rift, Djibouti and propose that a dyking event at depth triggered normal faulting. They found a very good fit of model predictions with seismogenic layer thickness and heat flow observations. Their models allow $>50 \%$ extension by magmatic intrusion.

The magmatic segments of the Ethiopian rift show a trend of increasing extension towards the north, as indicated by the deformed volcanic edifices and increase in number of identified faults from Boset-Kone $(N=123)$ to Fantale-Dofen $(N=164)$ magmatic segments (see Fig. 10). Seismic (Bastow et al. 2005; Maguire et al. 2006) and geochemical (Furman et al. 2006) data also show a south to north increase in the amount of crustal and mantle lithospheric thinning.

Using remote sensing, seismic, geochemical and geodetic data, and by analogy to the AsalGhoubbet rift zone, we can estimate the relative contribution of dyke intrusion and faulting to the total deformation. Synthesizing constraints on distribution of strain from field, the number of faults and their displacements do not appear adequate to account for all the strain recorded in the shapes of the volcanoes, nor predicted from geodetic models of Nubia-Somalia separation. One possibility is that there are large offset faults buried by lava flows, but one would expect flows to show the shape of the footwall uplift of these faults. Seismic data in Mackenzie et al. (2005) show no evidence for buried magmatic segment faults with offsets $>500 \mathrm{~m}$, the resolution in the upper $5 \mathrm{~km}$. Bendick et al. (2006) compared seismic moment release and geodetic strain across the MER along a line through the Boset-Kone magmatic segment, and concluded that faulting alone could not account for plate boundary deformation over the past two decades. All the faults appear to have dips of $60^{\circ}$ or greater and large displacements on normal faults rotates them to shallower dips. In addition, a large amount of extension on normal faults would lead to thinning detectable in EAGLE seismic data. Instead, only one fault with $>200 \mathrm{~m}$ throw is observed; it marks a basin, rather than the topographic highs seen in the Aluto-Gedemsa and Boset-Kone magmatic segments. The larger faults are matched by apparently higher magma production rates to the north (Bastow et al. 2005; Furman et al. 2006; Pik et al. 2003).

The right-stepping en echelon arrangement of magmatic segments, as well as the fault zones and aligned chains of eruptive centres along the length of magmatic segments, mark a segmentation distinct from the Miocenc border fault segmentation (e.g. Ebinger \& Casey 2001). Our observations indicate that magma intrusion processes largely control the extension and rupture processes in the MER, as was scen by Cattin et al. (2005) in the 
Asal-Ghoubbet rift. The segmentation in lowvelocity zones near the lithosphere-asthenosphere boundary beneath the MER implies localized melt production zones along the length of the rift (Bastow et al. 2005), but crustal contamination makes it difficult to evaluate along-axis trends in geochemical data from the Quaternary centres (e.g. Ayele et al. 2006; Furman et al. 2006). We find no evidence for cross-rift structures linking en echelon segments at the surface, or at depth. Gravity and crustal seismic data mirror the surface expression of the magmatic segments; crust beneath narrow magmatic segments is denser and high velocity, whereas intersegment zones are not anomalous (Keranen et al. 2004; Tiberi et al. 2005; Cornwell et al. 2006). Likewise, the lack of rotation about vertical axes in intersegment zones argues against distributed strain in these zones.

We suggest that the en echelon along-axis segmentation of the MER represents the interplay between Miocene-Pliocene rift structures and the nowfocused, localized magma intrusion zones marking the transition to seafloor spreading. The East African rift is linked to the Red Sea and Gulf of Aden rifts via the NE-striking northern MER, which itself is oblique to the remainder of the MER (e.g. Fig. 1). Maguire et al. (2006) and Bastow et al. (2005) propose an ancient suture zone of prerift structure cross-cutting the northem MER, possibly explaining the kink in the MER. The Miocene border faults are also oblique to the current extension direction, with a Pliocene transtensional episode recorded in fault patterns $\left(\mathrm{N} 10^{\circ} \mathrm{E}\right.$ extension along $\mathrm{N}^{\circ} 5^{\circ} \mathrm{E}$ faults; e.g. Bonini et al. 1998). Finally, the deep-seated thermal anomaly beneath the rift trends $\mathrm{NE}$ to connect with the Afar plume centre imaged in global tomographic models (e.g. Montelli $e t$ al. 2004). The right-stepping en echelon pattern of magmatic segments is attributed to the combination of a NE-trending magma source zone at the lithosphere-asthenosphere boundary and an artifact of the pre-Quaternary geological history.

Our results, supported by comparison to the recently ruptured Asal-Ghoubbet seafloor spreading centre, suggest that the along-axis segmentation of mid-ocean ridges initiates prior to lithospheric rupture in areas with a ready supply of magma.

\section{Conclusions}

Field, remote sensing and modelling studics integrated with EAGLE seismic results indicate that extension has localized to approximately $20 \mathrm{~km}$ wide zones of small offset faults and magmatism since Quaternary time. Extension within these $60 \mathrm{~km}$-long, right-stepping magmatic segments is accommodated by both faulting and magmatism.
Although extrusive volcanism masks some fault offsets, geophysical data indicate that stretching by faulting across the rift zone is minor, and the only large offset faults are the inactive Miocene border faults outboard from the magmatic segments. The elongation of eruptive centres, the localization of seismicity and magmatism, and the absence of large offset faults all indicate that magma intrusion and dyking play a larger role than faulting in strain accommodation as rifting progresses to seafloor spreading.

The right-stepping, en echelon pattern of magmatic segments, and the obliquity of Quaternary and Miocene-Pliocene structures, record changes in extension direction through time. NE-striking, Miocene-Pliocene faults were replaced by $\mathrm{N} 10_{-}$ $30 \mathrm{E}$-striking faults in late Pliocene time, resulting in a transtensional regime. With the localization of strain to the narrow magmatic segments after $2 \mathrm{Ma}$, extension was normal to the strike of normal faults and aligned eruptive centres; the older NE-striking faults act as oblique-slip linkage segments. The coincidence of volcanic edifice elongation directions, Quaternary fault slip indicators, and focal mechanism solutions (Keir et al. 2005) all indicate a $\mathrm{N} 105-110^{\circ} \mathrm{E}$ extension direction, in agreement with geodetic and plate kinematic models (e.g. Calais et al. 2006). The right-stepping en echelon pattern of magmatic segments is attributed to the combination of a NE-trending magma source zone at the lithosphere-asthenosphere boundary and the pattern of extension along border faults. The rates of extension inferred from volcano elongation estimates lie within the range of rates estimated from geodetic studies, assuming strain is localized to the $20 \mathrm{~km}$ wide magmatic segments. Total strain incrcases from south to north, consistent with the observed increase in crustal and mantle lithospheric thinning (e.g. Bastow et al. 2005; Maguire ef al. 2006).

Observations of Quaternary faults in the northern MER indicate that faults propagate upward, probably from mid- to upper crustal intrusion zones. Monoclines with open fissures mark a vertical crack above an upward-propagating, dipping fault plane. The stress concentrations at the propagating fault tips promote the extrusion of magma at these points. The deformation patterns observed in the northern MER are strikingly similar to patterns in the Asal-Ghoubbet and Iceland seafloor spreading centres where magma intrusion accommodates more strain than faulting.

We thank Laike Asfaw, Atalay Aycle. Bekele Abebe, Tesfaye Kidane, Tesfayc Korme, Ian Bastow, Ellen Wolfenden, Eve Daly, K. McClay, and Rosie Fletcher for discussion of field observations, and J.R. Rowland, J. Bull, and P.K.H. Maguire for very helpful revicws. 


\section{References}

Abebe, B., Boccaletti, M., Mazzuol, R., Bonint, M.L. \& TRUA, T. 1998. Geological map of the Lake Ziway-Asela region, Main Ethiopian Rift. ARCA-DB Map.

Acocella, V. \& Korme, T. 2002. Holocene extension direction along the Main Ethiopian Rift. East Africa. Terra Nova, 14, 191-197.

Acocell. , V., Korme, T. \& Salvini, F. 2003. Formation of normal faults along the axial zone of the Ethiopian Rift. Journal of Structural Geology. 25, 503-513.

AsFAw, L.M. 1982. Development of earthquake induced fissures. Nature, 286, 551-553.

ASFAw, L.M. 1992. Seismic risk at a site in the EastAfrican Rift System. Tectonophysics, 209, $301-309$.

ASFAw, L.M. 2006. Vertical deformation in the Main Ethiopian Rift: I evelling results in its northern part, 1995-2004. In: Yirgu, G., Ebinger, C.J. \& MagulRe, P.K.H. (eds) The Afar Volcanic Province within the East African Rift System. Geological Society, London, Special Publications, 259, $185-190$.

AyELE, A. 2000 . Normal left-oblique fault mechanisins as an indication of sinistral deformation between the Nubia and Somalia plates in the Main Ethiopian Rift. Journal of African Earth Sciences, 31, 359-367.

Ayel.e, D., Bourdon, E., Ebinger, C., Wolffinden, E., Yirgu, G. \& Grassineau, N. 2006. Temporal compositional variation of syn-rift rhyolite along the western margin of the Red Sea and northern Main Ethiopian Rift. In: YIRGU, G., EBINGER, C.J. \& MagurRt, P.K.H. (eds) The Afar Volcanic Province within the East African Rift System. Geological Society, London. Special Publications, 259, $121-130$.

Bastow, I., Stuart, G., Kendall, M. \& Ebinger, C. 2005. Upper mantle seismic structure in a region of incjpient continental breakup: northern Main Ethiopian Rift, Geophysical Journal Intermational, 162, 479-493.

Bellahsen, N., faccenna, C., Funicielloo, C., DANIEL, J.M. \& Jol.lveT, L. 2003. Why did Africa separate from Africa? Insights from 3D laboratory experiments. Earth and Planetary Science Letters, 216, 365-381.

Bendick, R., Bilham, R., Klemperer, S. \& Asfaw, L.M. 2006. Distributed Nubia-Somalia relative motion and dike intrusion in the Main Ethiopian Rift. Geophysical Journal International, (in press).

Benoit, M.H., Nyblade, A.A., VanDecar, J.C. \& Gurrola, H. 2003. Upper mantle P velocity structure and mantle transition zone thickness beneath the Arabian Shield. Geophysical Research Letters, 30, 1153.

Bilham, R., Bendick, R., LaRson, K., Braun, J., Tesfaye, S., Mohr, P. \& Asław, L. 1999. Secular and tidal strain across the Ethiopian rift. Geophysical Research Letters, 27, 2789-2984.
BJORNSSON, A. 1985. Dynamics of crustal rifting in Iceland. Journal of Geophysical Research, 90 , $151-162$.

Boccaletti, M., Bonini, M., Mazzuoli, R., Abere, B., Piccardi, L. \& Tortorici, L. 1998. Quaternary oblique extensional tectonics in the Ethiopian Rift (Horn of Africa). Tectonophysics, 287, 97-116.

Boccaletti, M., Mazzuoli, R., Bonini, L., Trua, T. \& ABEBE, B. 1999. Plio-Quaternary volcanotectonic activity in the northern sector of the Main Ethiopian Rift: Relationships with oblique rifting. Journal of African Earth Science, 29, 679-698.

Bonini, M., Souriot, T., Boccaletti, M. \& Brun, J.P. 1997. Successive orthogonal and oblique extension episodes in a rift zone: Laboratory experiments with application to the Ethiopian rift. Tectonics, 16, 347-362.

Buck, W.R. 2004. Consequences of asthenospheric variability on continental rifting. In: KARNER, G., TAYloR, B., DRISCOLl, N. \& KohISTEDT, B. (eds) Rheology and Deformation of the Lithosphere at Continental Margins. Columbia University Press, pp. 92-137,

Bull, J.M., Minshull, T., Mitchell, N., Dix, J.K. \& Hardardottir. L. 2006. Magmatic and Tectonic History of Icelands Western Rift at Lake Thingvallavatn. Geological Society of America Bulletin, 117, 1451-1465.

Calais, E., Ebinger, C., Hartnady, C. \& Nocquet, J.M. 2006. Mantle-driven plate motions in the East African Rift? In: Yirgu, G., Ebinger, C.J. \& Maguire, P.K.H. (eds) The Afar Volcanic Province within the East African Rift System. Geological Society, London, Special Publications, 259, 9-22.

Cattin, R., Doubre, C., de Chabalier, J.-B., KING, G., Vigny, C., Avouac, J.-P. \& RuegG, J.-C. 2005. Numerical modelling of Quaternary deformation and post-seismic displacement in the Asal-Ghoubbet rift (Djibouti. Africa). Earth and Planetary Science Letters, 239, 352-367.

Cervelli, P., Segall, P., Amelung, F., Garbeil, H. Meertens, C., OWen, S., Miklius, A. \& LISkowski, M. 2002. The 12 September 1999 upper East Rift Zone dike intrusion at Kilauea Volcano, Hawaii. Journal of Geophysical Research, 107, 1029/2001JB000602.

Chernet, T., Hart, W., Aronson, J. \& Walter, R.C. 1998. New age constraints on the timing of volcanism and tectonism in the northern Main Ethiopian Rift-southern Afar transition zone (Ethiopia). Journal of Volcanology and Geothermal Research, 80, 267-280.

Chernet, T. 2005. Geological and hydrothermal alteration mapping of the Dofen geothermal prospect and adjacent western escarpment (Ethiopia), Proceedings of the World Geothermal Congress. Antalya, Turkey, 24-29 April 2005.

Chu, D.H. \& Gordon, R.G. 1999. Evidence for motion between Nubia and Somalia along the Southwest Indian Ridge. Nature, 398, 64-67.

Cornwell, D.G., Mackenzie, G., Maguire, P.K.H., England, R., Asfaw, L.M. \& Oluma, B. 2006. 
Northern Main Ethiopian Rift crustal structure from new high precision gravity data. In: YIRGU, G., Ebinger, C.J. \& MAguiRe, P.K.H. (eds) The Afar Volcanic Province within the East African Rift System. Geological Society, London, Special Publications, 259, 307-321.

Colrtillot, V., Armijo, R. \& Tapponnier, P. 1987. The Sinai triple junction revisited. Tectonophysics, 141, 181-190.

Crouch, S.L. \& Starfield, A.M. 1983. Boundary Element Methods in Solid Mechanics. Allen \& Unwin, London.

De Chabalier, J.-B. \& Avouac, J.-P. 1994. Kinematics of the Asal Rift (Djibouti) determined from the deformation of Fieale Volcano. Science, $265,1677-1681$.

Dei.aney, P.T. \& Pollard, D. 1981. Deformation of host rocks and flow of magma during growth of minette dykes and breccia-bearing inclusions near Ship Rock. New Mexico. US Geological Survey Professional Paper, 1202.

Dugda, M., Nyblade, A., Julia. J., Langston, C.A., AMmon, C. \& SimiYU, S. 2005. Crustal structure in Ethiopia and Kenya from receiver function andlyses: Implication for rift development in eastern Africa. Journal of Geophwical Research, 110 , doi:10.1029/2004JB003065.

Ebincier, C.J. \& Casey, M. 2001. Continental breakup in magmatic provinces: An Ethiopian example. Geology, 29, 527-530.

Ebincier, C., Yemane, T., Harding, D., Tesfaye, S., RYX, D. \& KELJ.EY, S. 2000. Rift deflection, migration, and propagation: Linkage of the Ethiopian and Eastern rifts, Africa, Geological Society of America Bulletin, 102, 163-176.

Feigl, K., Gasperi, J., Sigmundsson, F. \& Rigo, A. 2000. Crustal deformation near Hengill volcano Iccland 1993-1998: Coupling between magmatic activity and faulting inferred from elastic modelling of satellite radar interferometry. Journal of Geophysical Research, 105, 25655-25670.

Fernandes, R.M.S., Ambrosius, B.A.C., NoOmen, R., Bastus, L., Combrinck, L. Miranda, J.M. \& SPAKMAN. W. 2004. Angular velocity of Nubia and Somalia from continuous GPS data: implications on present-day relative kinematics. Earth and Planetary Science Letters, 222, 197-208.

Furman, T., Bryce, J., RoOney, T., Hanan, B., YIRGU, G. \& AYAlLW, D. 2006. Heads and tails: 30 million years of the Afar Plume. In: Yirgu, G., Ebinger, C.J. \& Maguire, P.K.H. (eds) The Afar Volcanic Province within the East African Rift System. Geological Society, London, Special Publications, 259, 95-119.

Gibson, I. 1967. Preliminary account of the volcanic geology of Fantale, Shoa. Bulletin. Geophysical Observatory Addis Ababa, 10, 59-67.

Grant, J.V. \& Kattenhorn, S.A. 2004. Evolution of vertical faults at an extensional plate boundary, southwest Iceland. Journal of Structural Geology, 26, 537-557.

GLdmundsson, A. 1992. Formation and growth of normal faults at the divergent plate boundary in Iceland. Terra Nova, 4, 464-471.
GuptA, A. \& Scholz, C.H. 2000. Brittle strain transition in the Afar Depression: Implications for fault growth and seafloor spreading. Geology, 28. $1087-1090$.

HAYwaRd, N. \& Ebinger, C. 1996. Variations in along-axis segmentation of the Afar rift system. Tectonics, 15, 244-257.

Hofmann, C., Courtillot, V., Feraud, G. Rochette, P., Yirgu, G., Ketefo, E. \& Pik, R. 1997. Timing of the Ethiopian flood basalt event: implications for plume birth and global change. Nature, 389, 838-841.

Holbrook, W. \& Kelemen, P. 1993. Large igneous province on the US Atlantic margin and implications for magmalism during breakup. Nature, $364,433-436$.

Jonsson, S., EInARsson, P. \& Sigmundsson, F. 1997. Extension across a divergent plate boundary, the eastern Volcanic Rift Zone, south Iceland. 1967-1994, observed with GPS and electronic distance measurements. Journal of Geophysical Research, 102, 11913-11929.

Keir, D., Ebingler, C., Stuart, G., Dal.y, E. \& AYEI.E, A. 2006. Strain accommodation by magmatism and faulting as rifting proceeds to breakup: Seismicity of the northern Ethiopian Rift. Journal Geophysical Research (in press).

Kendall, J.-M., Stuart, G., Ebinger, C., Bastow, I. \& KEIR, D., 2005. Magma-assisted rifting in Ethiopia. Nature, 433, $146-148$.

Keranen, K., Klemperer, S.. Gluaguen, R. \& EAGI.E Working Group 2004. Imaging a protoridge axis in the Main Ethiopian Rift. Geology, 39. 949-952.

Kidane, T., Ebinger, C., Abebe, B., Pl.atzman, E., Keir, D., Lahitte, P. \& Rochette, P. 2006. Palacomagnetic constraints on continental breakup processes: Observations from the Main Ethiopian Rift. In: YrRgu. G., Ebinger, C.J. \& MagulRe, P.K.H. (eds) The Afar Volcanic Province within the East African Rift System. Geological Society, London, Specjal Publications. 259. $165-183$.

Kieffer, B., ARndt, N., ET Al. 2004. Flood and shield basalts from Ethiopia: Magmas from the African superswell. Journal of Petrology, 45, 793-834.

Korenaga, J., Hol.brook, W.S., ET AL. 2000. Crustal structure of the southeast Greenland margin from joint refraction and reflection seismic tomography. Journal of Geophysical Research, 105, 2159121614.

Maguire. P.K.H., Kei.Ler. G. ET AL. 2006. Crustal structure of the northern MER from the EAGLE controlled source survey: Snapshot of incipient lithospheric breakup. In: YIRGU, G., EBINGER, C.J. \& MAGLiRE, P.K.H. (eds) The Afar Volcanic Province within the East African Rift System. Geological Society, London, Special Publications, 259, 269-291.

Mackenzie, G., Thybo, H. \& Maglire, P.K.H. 2005. Crustal velocity structure across the Main Ethiopian Rift: Results from two-dimensional wideangle seismic modelling. Geophysical Joumal International, 162, 994-1006. 
MANDL, G. 1987. Discontinuous fault zones. Journal of Structural Geology, 9, 105-110.

Manighetti, I., Tapponnier, P.. Courtillot, V., Gruszow, S. \& Gillot, P.-Y. 1997. Propagation of rifting along the Arabia-Somalia plate boundary: The gulfs of Aden and Tadjoura. Journal of Geophysical Research, 102, 2681-2710.

Meyer, W., Pilger, A., Rosler, A. \& Stets, J. 1975. Tectonic evolution of the northern part of the Main Ethiopian Rift. In: Pilger, A. \& Rösler, A. (eds) Afar Depression of Ethiopia, Schweizerbart, Stuttgart.

MoHr, P.A. 1962. The Ethiopian Rift System. Bulletin of the Geophysical Observatory, Addis Ababa, 5. $33-62$.

Mohr, P.A. 1968. Transcurrent faulting in the Ethiopian Rift System. Nature, 218, 938-941.

MonTEl.l.I, R., NOLET, G., DAHLEN, F.A., ENGdAH1, E.R. \& Hung, S.H. 2004. Finitefrequency tomography reveals a variety of plumes in the mantle. Science, 303, 338-343.

Morton, W.H., Rex, D.C., Mitchell, J.G. \& MOHR, P.A. 1979. Riftward younging of volcanic units in the Addis Ababa region, Ethiopian Rift valley. Nature, 280, 284-288.

Pik, R., Marty, B., Carignan, J. \& Lave, J. 2003. Stability of the Upper Nile drainage network (Ethiopia) deduced from (U-Th)/He thermochronometry: Implications for uplift and erosion of the Afar plume dome. Earth and Planetary Science Letters, 215, 73-88.

Pizzi, A., Coltor'ti, M., Abebe, B.. Disperati, L., Saccili, G. \& Salvini, R. 2006. The Wonji fault belt (Main Ethiopian Rift): Structural and geomorphological constraints and GPS monitoring. In: Yirgu, G., Ebinger, C.J. \& Maguire, P.K.H. (cds) The Afar Volcanic Province within the East African Rift System. Geological Society, London, Special Publications, 259, 191-207.

Rooney, T., Furman, T., Yirgu, G. \& Ayalew, D. 2005. Structure of the Ethiopian lithosphere: Evidence from mantle xenoliths. Geochimica et Cosmochimica Acta, 69, 3889-3910.

RUBIN, A. 1992. Dike-induced faulting and graben subsidence in volcanic rift zones. Journal of Geophysical Research, 97, 1839-1858.

RuBin, A.M. \& Pollard, D.D. 1988. Dike induced faulting in rift zones in Iceland and Afar. Geology, 16, 413-317.
Sigmundsson, F., Einarsson, P., Rognvaldsson, S.T., Foulger, G.R., Hodgkinson, K.R. \& ThORBERgSSON, G. 1997. The 1994-1995 seismicity and deformation at the Hengill triple junction, Iceland: Triggering of earthquakes by minor magma injection in a zone of horizontal shear stress. Journal of Geophysical Research, 102, $15151-15161$.

Stuart, G., Bastow, I. \& Ebinger, C. 2006. Crustal structure of the northern Main Ethiopian Rift from receiver function studies. In: YIRGU, G., EBINGER, C.J. \& MagulRz, P.K.H. (eds) The Afar Volcanic Province within the East African Rift System. Geological Society, London. Special Publications, 259, 253-267.

Tesfaye, S., Harding, D.J. \& Kusky, T. 2003. Early continental breakup boundary and migration of the Afar Triple Junction, Ethiopia. Geological Society of America Bulletin, 115, $1053-1067$.

Tiberi, C., Ebinger, C., Balllu, V., Stuart, G. \& OLuMA, B. 2005. Inverse models of gravity data from the Red Sea-Aden-East African Rifts triple junction zone. Geophysical Joumal international, 163, 775-787.

Williams, F., Williams, M. \& Aumento, F. 2004. Tensional fissures and crustal extension rates in the northern part of the Main Ethiopian Rift. Journal of African Earth Sciences, 38, 183-197.

WOldeGabriel, G., ARONSON, J. \& Walter, R. 1990. Geology, geochronology, and rift basin development in the central sector of the Main Ethiopian Rift. Geological Society of America Bulletin, 102, 439-458.

Wolffinden, E., Ebinger, C., Yirgu, G., Deino, A. \& AYALFW, D. 2004. Evolution of the northern Main Ethiopian Rift: Birth of a triple junction. Earth and Planesary Science Letters, 224, 213-228.

Wolfenden, E., Ebinger, C., Yirgu, G., Renne, P. \& Kelley, S.P. 2005, Evolution of the southern Red Sea rift: Birth of a magmatic margin. Bulletin of the Geological Society of America, 117, $846-864$.

WRIGHT, D.J., HAYMON, R.M. \& FORNARI, D.J. 1995. Crustal fissuring and its relationship to magmatic and hydrothermal processes on the East Pacific Rise crest (9-degrees-12' to 54' N), Journal of Geophysical Research, 100, 6097-6120. 